\title{
T cell pathology in skin inflammation
}

\section{Robert Sabat ${ }^{1} \cdot$ Kerstin Wolk ${ }^{1,2} \cdot$ Lucie Loyal $^{2} \cdot$ Wolf-Dietrich Döcke ${ }^{3} \cdot$ Kamran Ghoreschi $^{4}$}

Received: 12 February 2019 / Accepted: 22 March 2019 / Published online: 26 April 2019

(C) The Author(s) 2019

\begin{abstract}
Forming the outer body barrier, our skin is permanently exposed to pathogens and environmental hazards. Therefore, skin diseases are among the most common disorders. In many of them, the immune system plays a crucial pathogenetic role. For didactic and therapeutic reasons, classification of such immune-mediated skin diseases according to the underlying dominant immune mechanism rather than to their clinical manifestation appears to be reasonable. Immune-mediated skin diseases may be mediated mainly by $\mathrm{T}$ cells, by the humoral immune system, or by uncontrolled unspecific inflammation. According to the involved T cell subpopulation, T cell-mediated diseases may be further subdivided into T1 cell-dominated (e.g., vitiligo), T2 cell-dominated (e.g., acute atopic dermatitis), T17/T22 cell-dominated (e.g., psoriasis), and Treg cell-dominated (e.g., melanoma) responses. Moreover, T cell-dependent and -independent responses may occur simultaneously in selected diseases (e.g., hidradenitis suppurativa). The effector mechanisms of the respective $\mathrm{T}$ cell subpopulations determine the molecular changes in the local tissue cells, leading to specific microscopic and macroscopic skin alterations. In this article, we show how the increasing knowledge of the $\mathrm{T}$ cell biology has been comprehensively translated into the pathogenetic understanding of respective model skin diseases and, based thereon, has revolutionized their daily clinical management.
\end{abstract}

Keywords Skin inflammation $\cdot$ Immune-mediated disease $\cdot$ IL-4 $\cdot$ IL-17 $\cdot$ IL-22 $\cdot$ IFN- $\gamma \cdot$ TNF- $\alpha \cdot$ TGF- $\beta$

\section{Introduction}

As the barrier between the organism and the environment, the skin protects against external hazards, noxious substances,

Robert Sabat and Kerstin Wolk contributed equally to this work.

This article is a contribution to the special issue on The Pathogenicity of Acquired Immunity in Human Diseases - Guest Editor: Kiyoshi Hirahara

Robert Sabat

robert.sabat@charite.de

Kamran Ghoreschi

kamran.ghoreschi@charite.de

1 Psoriasis Research and Treatment Center, Department of Dermatology, Venereology and Allergology/Institute of Medical Immunology, Charité - Universitätsmedizin Berlin, Charitéplatz 1, 10117 Berlin, Germany

2 Berlin-Brandenburg Center for Regenerative Therapies (BCRT), Charité - Universitätsmedizin Berlin, Augustenburger Platz 1, 13353 Berlin, Germany

3 SBU Oncology, Pharmaceuticals, Bayer AG, Berlin and Wuppertal, Müllerstraße 178, 13353 Berlin, Germany

4 Department of Dermatology, Venereology and Allergology, Charité Universitätsmedizin Berlin, Charitéplatz 1, 10117 Berlin, Germany and pathogens. It is the largest and heaviest human organ and is built up by three distinct layers: the outermost epidermis, the dermis, and the subcutis [1-3]. The numerically dominant cell population of the continuously renewing epidermis is that of keratinocytes. Proliferation of these cells usually takes place within the stratum basale (attached to the basement membrane). Here, the epidermal stem cells are situated, which, upon their rare divisions, deliver the so-called transit amplifying cells (TA cells), a frequently proliferating population $[1,4]$. Each division of an individual TA cell delivers a daughter cell able to leave the basement membrane and to start terminal differentiation in the suprabasal stratum spinosum. During terminal differentiation, these cells move upward, becoming granular (stratum granulosum) and undergoing a particular apoptotic process to become horny constructs. Tightly covering the skin surface, these so-called corneocytes form the uppermost layer of the epidermis, the stratum corneum [1-3]. Under normal conditions, there is a balance between stem cell proliferation, TA cells, terminal differentiation, and the continuous desquamation of corneocytes from the skin surface (about 50 billion daily). This equilibrium is markedly disrupted in some chronic immune-mediated skin diseases [5]. Besides keratinocytes, Merkel cells, melanocytes, and 
immune cells, including Langerhans cells and resident memory CD8+ T cells, are also present in the epidermis $[6,7]$. The dermis, lying under the epidermis, consists of connective tissue containing collagenous, elastic, and reticular fibers as well as fibroblasts and hosts immune cells like macrophages, immature dendritic cells (DCs), mast cells, and some resident memory CD4+ T cells.

The permanent contact of the skin with exogenous stimuli and antigens frequently leads to activation of the resident immune cells. The cutaneous persistence of the stimulus/antigen and/or a relative deficiency of counter-regulatory mechanisms, particularly in the context of a genetic predisposition, results in local immune cell infiltration and chronic activation, which also involves the cutaneous tissue cells. Hence, it is not surprising that chronic immune-mediated skin diseases are some of the most common disorders in humans. For the affected patients, these diseases induce not only physical but also psychological burdens due to the visibility of the symptoms and the frequent association with itching, pain, and burning [8-10]. They may be primarily mediated by the uncontrolled activation of $\mathrm{T}$ cells, the humoral immune system, or unspecific inflammation (innate immunity). Disorders dominated by pathogenic CD4+ and/or CD8+ T cells comprise the largest group within the chronic immune-mediated skin diseases [11]. A deeper understanding of the molecular and cellular mechanisms underlying these disorders might lead to the identification of novel target molecules and, as a consequence, to the development of innovative therapeutic strategies. In this review, we will discuss the mechanisms of development and maintenance of specialized $\mathrm{T}$ cell subtypes and refer to representative diseases, in which the specific $\mathrm{T}$ cell subtypes play a crucial pathogenic role.

\section{Characteristics, development, and functions of $\mathrm{T}$ cell subpopulations}

T cells, a central component of the adaptive immunity, play a pivotal role in the defense against pathogens and tumors, while their dysregulation contributes to the development and maintenance of various diseases. T cells mature in the thymus, where they undergo somatic gene rearrangement resulting in the expression of a unique T cell receptor (TCR) [12]. During the positive selection process, detection of antigens presented on major histocompatibility complex class 1 (MHCI) or class 2 (MHCII) by the rearranged TCR implements either a CD8+ or CD4+ T cell lineage fate, respectively [13]. Presentation of autoantigens in the thymic medulla ensures the elimination of autoreactive $\mathrm{T}$ cells [14], and remaining T cells egress into circulation where they patrol blood and lymph as CD45RA+ CCR7+ naïve T cells [15].

When $\mathrm{T}$ cells bind their cognate antigen by the TCR accompanied by a sufficient co-stimulatory signal, they become activated, start proliferating, and contribute to pathogen clearance as effector cells [16]. After pathogen clearance, $95 \%$ of the effector cells undergo apoptosis; the remaining T cells give rise to a highly specialized set of memory cells that have lost CD45RA expression and instead express CD45RO [17]. The memory compartment can be subdivided into CCR7+ central memory $\left(\mathrm{T}_{\mathrm{CM}}\right)$, CCR7- effector memory $\left(\mathrm{T}_{\mathrm{EM}}\right)$, and CCR7effector memory $\mathrm{T}$ cells re-expressing CD45RA ( $\mathrm{T}_{\text {EMRA }}$ ) [15]. While $\mathrm{T}_{\mathrm{CM}}$ migrate through lymphatic tissue and were described to be less responsive, $\mathrm{T}_{\mathrm{EM}}$ patrol peripheral tissues and provide rapid effector function upon reactivation [15]. Single-cell-based experiments suggest a progressive maturation of $T$ cells from naive via $T_{C M}$ and $T_{E M}$ to $T_{E M R A}$ cells that are associated with chronic activation and display features of exhaustion such as impaired cytokine secretion and the expression of exhaustion markers such as programmed death-1 (PD-1) and TIM3 [18-20]. Upon migration into the different lymphoid and non-lymphoid tissues, some memory $\mathrm{T}$ cells gain tissue residency characterized by the upregulation of CD69 and CD103, the hallmarks of tissue-resident memory $\mathrm{T}$ cells $\left(\mathrm{T}_{\mathrm{RM}}\right)$, as well as expression of Hobit and Blimp1, which together suppress the re-egress into circulation [21]. Those cells exhibit an outstanding long-term maintenance and act as sentinels that protect against re-infections.

Antigen detection by CD4+ T cells is restricted to MHCII expressed on professional antigen-presenting cells (APCs) including dendritic cells (DCs), B cells, and macrophages [22]. These APCs continuously sample proteins and present peptides derived thereof on their surface. In the presence of conserved pathogenic structures or danger signals that are released by distressed cells, they become activated and migrate to the secondary lymphoid organs, where they in turn activate CD4+ T cells $[23,24]$. A central role of CD4+ T cells is to migrate into $\mathrm{B}$ cell follicles upon activation, where they mediate B cell help by CD40L:CD40 interaction. This CD40Lmediated help is indispensable for the induction of germinal center formation, antibody class switch, and somatic hypermutation [25]. During T cell activation, the cytokine milieu at the site of infection moreover modulates the differentiation and subsequent specialization of the T cells, allowing pathogen-tailored responses. The cytokines IL-12 and IFN- $\gamma$ induce the expression of the transcription factor T-bet in $\mathrm{T}$ cells, resulting into IFN- $\gamma$-producing type 1 helper (Th1) T cells that contribute to the clearance of virus-infected cells and intracellular pathogens [26]. Induction of Gata3 expression by IL-4 gives rise to type 2 helper (Th2) cells secreting IL-4, IL5 , and IL-13, which are critical mediators of extracellular parasite expulsion and mediate B cell class switch [27]. In recent years, the spectrum of CD4+ T cell subsets rapidly broadened by the identification of type 17 and type 22 helper (Th17, Th22), T follicular helper (Tfh) and regulatory (Treg) T cells. Th17 cells differentiate upon ROR $\gamma \mathrm{t}$ expression and produce IL-17 that induces epithelial antimicrobial defense and leads 
to recruitment and activation of neutrophils [28]. The work of Acosta-Rodriguez et al. suggests that IL-17-producing cells are a heterogeneous population consisting of Th17 cells dominating anti-fungal responses, whereas Th17+1 cells additionally secrete IFN- $\gamma$ and are the main responders in the defense of extracellular bacteria [29]. Th22 cells differentiate upon aryl hydrocarbon receptor expression, act on epithelial cells like keratinocytes by IL-22 secretion, and promote wound healing and tissue protection against damage [30]. Upon activation, some naïve CD4+ T cells upregulate the transcription factor Bc16 and migrate into B cell follicles where they become resident $\mathrm{T}$ fh cells contributing to germinal center formation $[31,32]$. In contrast, FoxP3+ Treg cells do not contribute to pathogen defense but instead prevent autoimmune disorders by suppressing unwanted immune responses [33]. The major population of CD4+ Treg cells was found to be characterized by high expression of the IL-2 receptor alpha chain (CD25), and the transcription factor FoxP3, the latter being indispensable for the development and suppressive function of Treg cells $[34,35]$.

Extensive analyses of the CD4+ T cell subsets revealed differing migration abilities, which are reflected by the expression of unique sets of chemokine receptors that mediate migration along a chemokine gradient. Combinations of the chemokine receptors CCR4, CCR6, CCR10, and CXCR3 were identified as separators of Th1 (CCR6CCR4-CXCR3+), Th2 (CCR6-CCR4+CXCR3-), Th17+1 (CCR6+CCR4-CXCR3+), Th17 (CCR6+CCR4+CXCR3CCR10-), and Th22 (CCR6+CCR4+CXCR3-CCR10+) cells [29, 36, 37]. CCR6 expression is-together with CD161-a common feature of IL-17-secreting cells [29, $38,39]$. The ligand for CCR6 is CCL20, which is predominantly produced by epithelial cells, organ-associated lymphoid tissues, and liver, allowing a broad migration pattern that is specified by the co-expression of further chemokine receptors [40]. In contrast, CCR4 and CCR 10 expression is implemented by DCs in skin-draining lymph nodes and allows the chemotactic migration along CCL17/CCL22 and CCL27/28, respectively [41, 42]. CCR4- and CCR10-expressing T cells co-express the so-called cutaneous leukocyte-antigen (CLA) and altogether mediate homing into the skin [43]. CXCR3 binds to CXCL9, CXCL10, and CXCL11, which are secreted in the presence of IFN- $\gamma$ and recruit CXCR3 + cells to sites of inflammation (reviewed in [44]). Beyond, the expression of CXCR5 is characteristic of Tfh cells, which binds the chemokine CXCL13 secreted by the follicular stroma, allowing the recruitment into the B cell follicle zones [45]. This concerted differentiation of $\mathrm{T}$ cells orchestrated by DCs ensures the right response at the right place in the body. CD4+ T cells possess a broad flexibility regarding the subset they differentiate into. By comparison of the TCR clone repertoire in Mycobacterium tuberculosis and Candida albicans infection, Becattini et al. could demonstrate overlaps in the clones found in the different CD4+ helper subsets, suggesting that priming of a single naïve CD4+ T cell can give rise to multiple fates [46].

In contrast to CD4+ T cells, CD8+ T cells were described cytotoxic $\mathrm{T}$ lymphocytes (Tc) that directly kill malign or infected cells. They detect antigens presented by MHCI, which is expressed by almost every cell in the body, to either eliminate the cell by the secretion of cytolytic molecules including perforin and granzymes or to induce Fas-mediated apoptosis (reviewed in [47]). In the memory stage, most (Tc1) cytotoxic CD8+ T cells express the transcription factor T-bet and secrete high levels of IFN- $\gamma$. However, some CD $8+T$ cells were identified that express Gata3 and display a type 2 cytotoxic (Tc2) T cell phenotype with secretion of IL-4, IL-5, and IL-13. Comparable with their CD4+ Th2 counterparts, they possess a CCR4+ and CRTH2+ phenotype [48]. Effector profiles of $\mathrm{CD} 8+\mathrm{T}$ cells in multiple diseases such as psoriasis vulgaris demonstrated that, among memory $\mathrm{CD} 8+\mathrm{T}$ cells, also IL-17, IL-22, and IL-17/IFN- $\gamma$ producers exist [49]. We could demonstrate that the CD8+ T cell subsets Tc1, $\mathrm{Tc} 2, \mathrm{Tc} 17, \mathrm{Tc} 1+1$, and Tc22 express the same set of chemokine receptors and utilize the same differentiation programs based on T-bet, Gata3, ROR $\gamma \mathrm{t}$, and aryl hydrocarbon receptor as do CD4+ $\mathrm{T}$ cells (Loyal et al., manuscript under review). While Tc1 and Tc17+1 CD8+ T cells display a classical cytotoxic phenotype, Tc2, Tc17, and Tc22 lack the capability to kill target cells and express the Th cell-typical molecule CD40L instead (Loyal et al., manuscript under review; [50]). In contrast to CD4+ T cells, the differentiation flexibility is restricted among CD8+ T cells, with a certain flexibility to gain $\mathrm{Tc} 1$ or $\mathrm{Tc} 17+1$ phenotype on the one side or to gain Tc2, Tc17, or Tc22 phenotype on the other side, but with very little clonal overlap between these two groups (Loyal et al., manuscript under review). They share the ability to secrete IL-13 and provide CD40Ldependent help (Loyal et al., manuscript under review; [50]). This striking effect might be caused by the site of priming, the involved APC, the priming conditions, and especially the type of antigen that gives rise to non-cytotoxic, "helper-type" CD8+ T cells. Their chemokine receptor expression, effector profile, and lack of cytotoxicity suggest a tissue homeostasis-maintaining function instead of contribution to the elimination of infected/malign/ distorted cells. Cheuk et al. demonstrated that, in human skin, a significant fraction of CD8+ T cells lack cytotoxic features including the expression of CD49a and instead produce IL-17 [51]. In a murine model, those skin Tc17 cells were shown to contribute to wound healing by IL-13 release upon recognition of non-classical MHCI (H2-M3)presented peptides derived from commensal bacteria [52, 53]. Altogether, $\mathrm{CD} 4+$ and $\mathrm{CD} 8+\mathrm{T}$ cells provide a broad 
repertoire of highly specific features and functions adapted to the diverse spectrum of challenges such as infections but also tissue homeostasis, wound healing, and tolerance as summarized in Fig. 1.

Besides their role in pathogen defense, the activation of skin-directed $\mathrm{T}$ cells can lead to chronic $\mathrm{T}$ cell-mediated skin diseases, whose characteristics correspond to the specific effector mechanisms of the different $T$ cell subpopulations. In fact, those diseases may be dominated by a Th/ c1-specific (e.g., vitiligo), Th/c2-specific (e.g., acute stage of atopic dermatitis), or Th/c17-/Th/c22-specific (e.g., psoriasis) pattern. Moreover, the activation of Treg cells is associated with skin tumors like melanoma, a malignant condition derived from melanocytes. Finally, T cell responses may be paralled by non- $\mathrm{T}$ cell responses, as in the case of hidradenitis suppurativa, where T17 cell activation $[54,55]$, a relative deficiency in Treg cells [56], and strong unspecific inflammation [57] have been found.

Since, as described above, the classical division of T cells into CD4+ helper $\mathrm{T}$ cells and CD8+ cytotoxic $\mathrm{T}$ cells has become out of date, the following sections will use the terms T1, T2, T17, T22, and Treg cells. The role of specialized T cells in representative skin diseases will be discussed in the following.

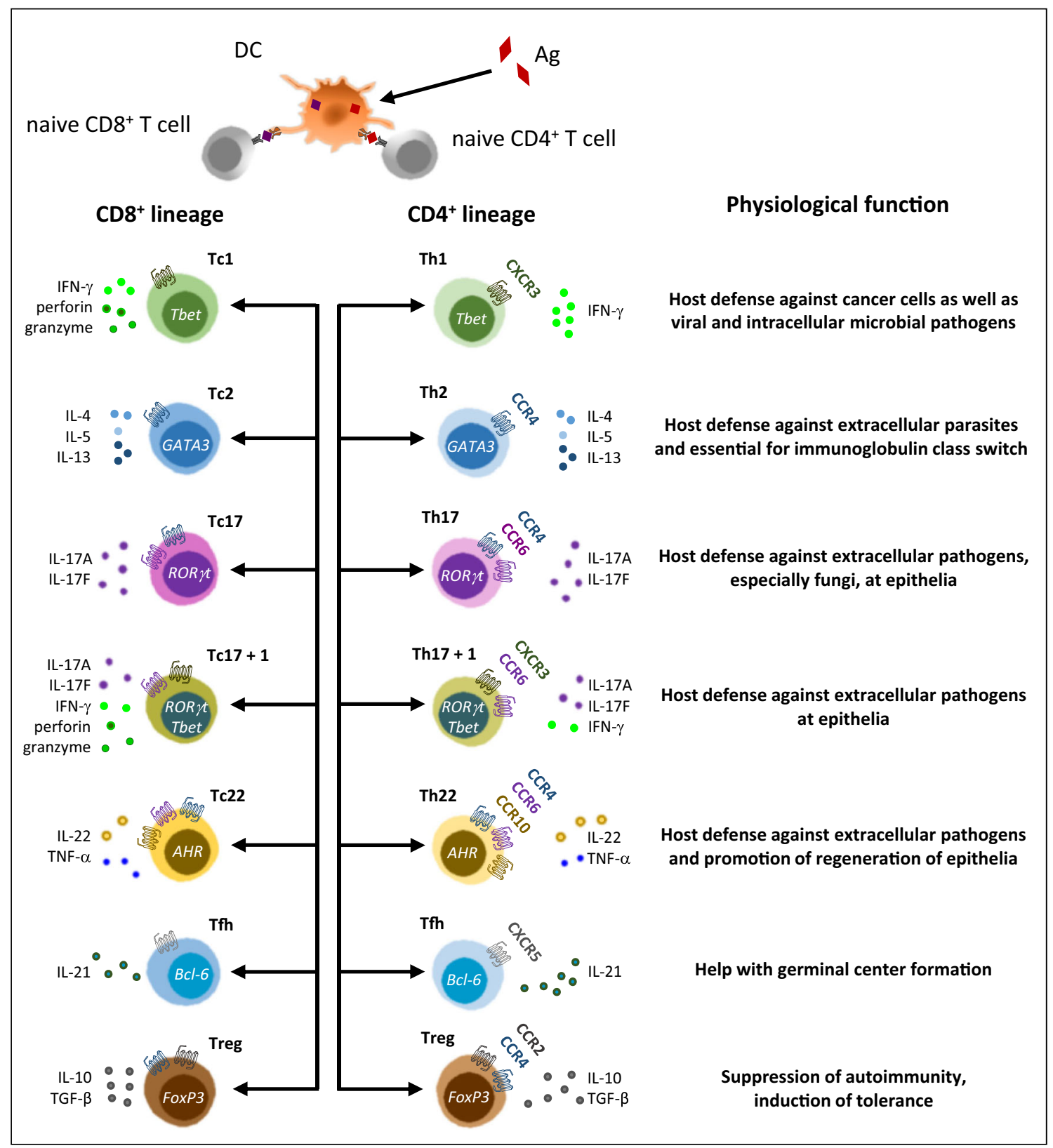

Fig. 1 Phenotype and function of T cell subsets 


\section{Common T cell-related skin disorders}

\section{T1 cells and vitiligo}

\section{Epidemiology, clinical, and histological characteristics}

Vitiligo is a chronic disease characterized by the appearance of pigment-free patches of the skin and rarely of the mucosa. In Europe, about $0.5-2 \%$ of people suffer from vitiligo. However, the prevalence of vitiligo in, e.g., India and Arabic countries, is appreciably higher $[58,59]$. Both sexes are equally affected, and a quarter of the cases concern children [60]. Typically, the vitiligo patches are sharply demarcated and differ in shape and size [58, 61]. However, apart from the depigmentation, they are macroscopically very similar to intact skin. Periorbital, perioral, and acral regions of the body are often affected. During the course of the disease, the number and size of the depigmented patches can increase, and patches can coalesce. As expected from the loss of pigment, the histological examination of vitiligo patches shows lack of melanocytes and melanin-containing keratinocytes in the stratum basale [61, 62]. During the early stage, a perivascular lymphocyte infiltration is observed in the dermis. In the late stage, though, the lymphocytes are mainly present at the edge of the patches [62].

\section{Immunopathophysiology of vitiligo}

Every tenth cell in the stratum basale of healthy skin is a melanocyte, and - under physiological conditions - melanocytes are not attacked by the immune system. However, melanocytes can be targeted or even destroyed by $\mathrm{T}$ cellmediated immune responses initiated by autoimmune processes or therapeutic intervention. Like in other autoimmune diseases, genetic predisposition is also present in individuals with vitiligo. Besides certain HLA genotypes, patients with vitiligo can show single nucleotide polymorphisms (SNPs) within genes that are implicated in $\mathrm{T}$ cell signaling or activation (NLRP1, TICAM1, FOXP3, BACH2, $P T P N 22, C D 80)$ or genes associated with cytotoxic T cell responses $(G Z M B, I L 2 R A)$ [60]. Nonetheless, the role of genetic predisposition in vitiligo etiology seems to be less important than that in other chronic T cell-mediated diseases like psoriasis or atopic dermatitis. In fact, only $1-10 \%$ of vitiligo patients have a positive family history for vitiligo in contrast to about $30 \%$ in the case of psoriasis.

It is generally accepted that the first step in vitiligo pathogenesis is a slight damage of melanocytes, e.g., by ultraviolet (UV) radiation or chemical substances. Such damage leads to an increase of reactive oxygen species (ROS), in particular when low levels of enzymatic and non-enzymatic antioxidants are present [63]. In fact, the impairment of the nuclear factor E2-related factor 2 (Nrf2), a protein important for protection against oxidative stress, seems to be critical for the increased sensitivity of vitiligo melanocytes to oxidative stress [64] as observed in lesional and non-lesional skin of patients. ROS and respective chemical substances provoke alteration of the folding machinery of the endoplasmic reticulum, leading to accumulation of immature proteins and finally to autophagy or apoptosis [60]. The increase of ROS is associated with the release of melanocyte-specific antigens and molecules like heat-shock proteins (HSPs) and self RNA/DNA, which activate pathogen recognition receptors on macrophages and DCs [63]. As reported, inducible HSP70 promotes an inflammatory DC phenotype and accelerates disease progression in a murine model of vitiligo [65].

The described events induce generation of $\mathrm{T} 1$ cells in lymph nodes that are specific for melanocyte antigens (Fig. 2). The infiltration of such T cells into the skin seems to depend on the chemokine receptor CXCR3 expressed by T1 cells and its ligands CXCL9, CXCL10, and CXCL11 produced by cutaneous tissue cells like keratinocytes [66]. Interestingly, vitiligo mouse models suggest that CXCL9 promotes Tc1 recruitment into the skin but not their effector function, whereas CXCL10 is required for effector function [67]. In the progressive phase of the disease, the immigrated $\mathrm{T} 1$ cells, in particular Tc1 cells, destroy melanocytes through the production of IFN- $\gamma$ and TNF- $\alpha$ as well as cytotoxic molecules like granzyme B and perforin [51] (Fig. 2). In fact, $\mathrm{Tc} 1$ cells isolated from the edges of patches induced apoptosis in autologous melanocytes in co-cultures in vitro [68]. Furthermore, IFN- $\gamma$ induces CXCL9 and CXCL10 in cutaneous tissue cells [69]. In contrast, the Treg cell response in the skin of patients with vitiligo seems to be limited [70], so that Treg cells are not able to prevent the cytotoxic IFN- $\gamma$ dominated T1 cell response [71]. Of note, individuals with vitiligo have a lower risk for developing malignant melanoma (see below). This observation shows that immune activation directed against melanocytic antigens can be of benefit in the setting of carcinogenesis.

Besides IFN- $\gamma$, IL-17 expression is also increased in perilesional skin of vitiligo patients, where $\mathrm{T}$ cells appear as the main source of this cytokine [72]. Since depigmentation is not a typical finding in psoriasis, a disease with high IL-17 expression in the skin, it is questionable, whether IL-17 significantly contributes to vitiligo pathogenesis.

\section{Immunopathology-based therapy of vitiligo}

Treating vitiligo is a challenge, since no systemic therapies are yet available. Understanding the exact pathogenetic processes in vitiligo could help in developing successful therapeutic strategies (Table 1). The dominant role of IFN- $\gamma$ in the depigmentation in mouse models of vitiligo [73] suggests that neutralizing this cytokine, inhibiting its production or signaling pathway, may help 
Fig. 2 Immunopathophysiology of vitiligo

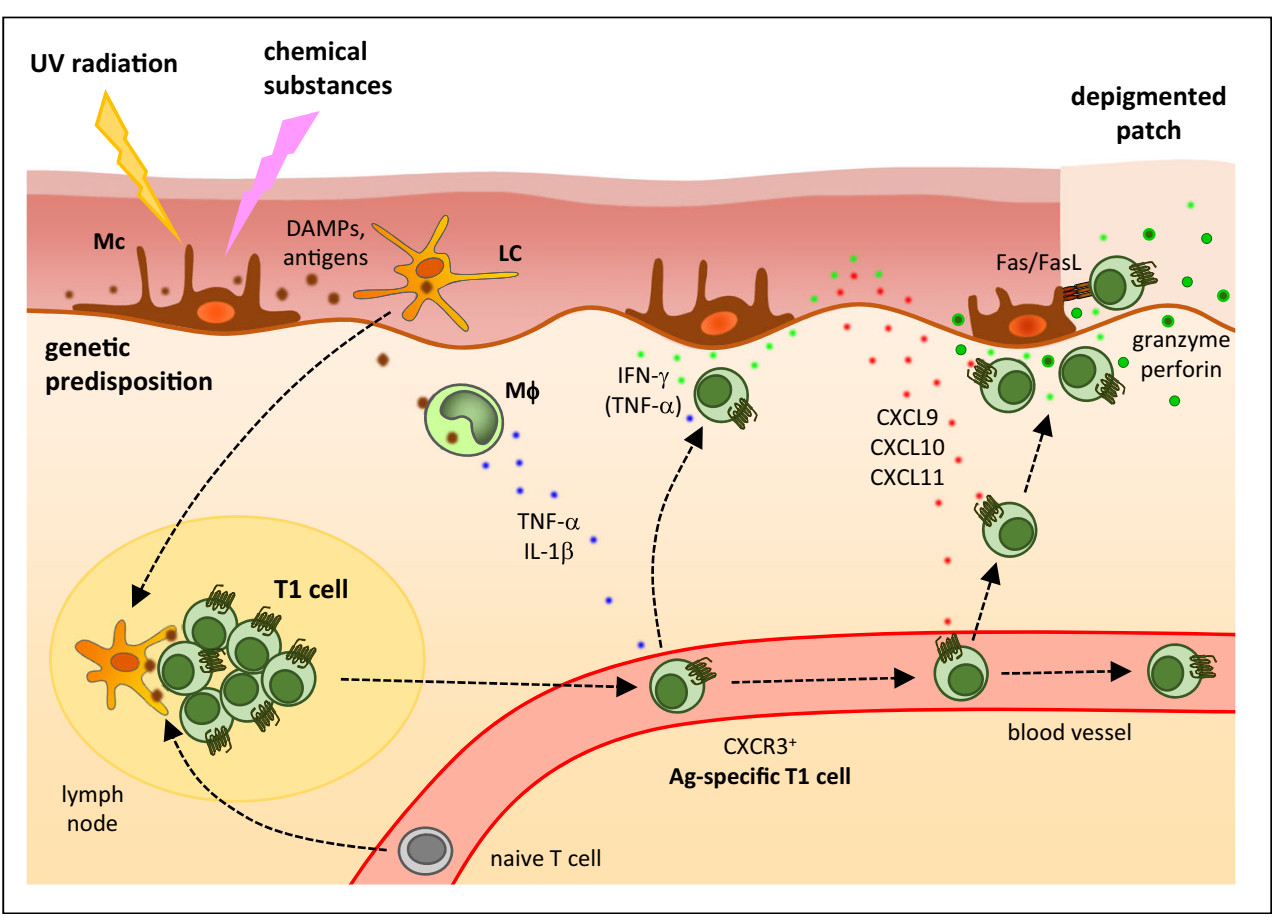

to stop the disease. More recently, two case reports described that patches rapidly repigmented in vitiligo patients treated with JAK inhibitors like tofacitinib or ruxolitinib that interfere with IFN- $\gamma$ signaling [74]. Since cumulating reports show that pathogenic T1 cells in vitiligo are tissue-resident memory $\mathrm{T}$ cells, interventions focused on IFN- $\gamma$ neutralization or hindrance of the effect of this cytokine should be periodically repeated [51]. Besides IFN- $\gamma$ as cytokine factor, T cell-based cytotoxic mechanisms are involved in melanocyte destruction. Thus, the depletion of T1 cells or the inhibition of their migration into the skin may result in promising approaches. The minimization of skin infiltration by $\mathrm{T} 1$ cells might be achieved by inhibiting CXCR3 function, as demonstrated in experimental mice [67]. Targeting the CXCR3 chemokine receptor to deplete T1 cells from skin is another alternative approach, as also recently demonstrated in mice [75]. Interestingly, this latter approach did not only prevent depigmentation but also lead to perifollicular re-pigmentation.

\section{T2 cells and atopic dermatitis}

\section{Clinical and histological picture of atopic dermatitis}

A more frequent $\mathrm{T}$ cell-mediated skin disease than vitiligo is atopic dermatitis. It usually begins in infancy. Its prevalence is very high in the Western population, with $15-20 \%$ of children and $3-4 \%$ of adults being affected [10]. The clinical manifestation of atopic dermatitis is age- and stage-dependent. While, in infants, skin lesions occur especially in the face and on the scalp, at later age, the flexural surfaces of the elbows and knees, the hands, feet, and the neck are increasingly affected. Acute lesions present as strongly itchy with red papules, serous exudation, and crusting. Histologically, edemas, vesiculation, and moderate hypogranularity and hyperkeratosis can be observed in the epidermis. Immune infiltration of the skin includes T cells, mast cells and eosinophilic granulocytes, macrophages, and DCs. Chronic lesions show increased collagen deposition in the dermis resulting in skin lichenification. Microscopically, acanthosis and more macrophage-dominated

Table 1 Pipeline of drugs for systemic treatment of vitiligo

\begin{tabular}{|c|c|c|c|c|c|c|}
\hline Target(s) & Drug name & Phase & Company & Trial ID & Study start & Status \\
\hline CD80/CD86 & Abatacept & 1 & Bristol-Myers Squibb & NCT02281058 & 1.2015 & Active, not recruiting \\
\hline PDE4 & Apremilast & 2 & Celgene & NCT03036995 & 3.2017 & Active, not recruiting \\
\hline Jak3 & PF-06651600 & $2 \mathrm{~b}$ & Pfizer & NCT03715829 & 11.2018 & Recruiting \\
\hline Tyk2/Jak1 & PF-06700841 & $2 b$ & Pfizer & NCT03715829 & 11.2018 & Recruiting \\
\hline
\end{tabular}

Source: Clinicaltrials.gov. Clinical trials that started after January 2012 are shown 
dermal infiltrations are visible at this stage. In contrast to psoriasis, lesions are less clearly demarcated [76]. In addition to the cutaneous alterations, $80 \%$ of patients suffer from allergies and often develop allergic asthma and rhinitis (extrinsic disease) [77].

\section{Immunopathophysiology of atopic dermatitis}

Atopic dermatitis has a multifactorial nature with a genetic component and environmental factors being involved (Fig. 3). A positive family history has been reported in 40 $60 \%$ of patients $[78,79]$. The strongest genetic association concerns the gene encoding the skin-barrier molecule filaggrin $(F L G)$. In fact, $20-30 \%$ of patients carry a $F L G$ null mutation [80]. This matches the fact that the impaired skin barrier is an essential factor in the pathogenesis and correlates with the severity of this disease [81]. Atopic dermatitis has also been linked to variants within the genes encoding the T2 pathwayassociated cytokines/cytokine receptors IL-4, IL-13, IL-4RA, and IL-31 and associated downstream molecules like STAT6 and GATA3 [82]. A characteristic MHC variant reported in some patient populations with atopic dermatitis is HLADRB1 [83]. Exogenous triggers of the disease include allergens, microbial antigens/superantigens, mental stress, and scratching of the skin [76].

$\mathrm{T} 2$ cell mediators are crucial for the pathogenesis of atopic dermatitis [80] (Fig. 3). At the chronic disease stage, the T22 mediator IL-22 is also of relevance [84, 85]. IL-4, IL-13, IL31 , and IL-22 seem to interfere with keratinocyte terminal differentiation [86-89]. This may explain the decreased epidermal expression of filaggrin and other molecules necessary for skin differentiation and barrier function even in patients without $F L G$ mutation. IL-31 is involved in the pathophysiology of itching, a characteristic finding patients with atopic dermatitis suffer from. IL-5 is known to activate eosinophilic granulocytes that are found histologically in skin lesions from the patients. IL-4 also promotes production of IgE, which shows elevated serum levels in the majority of patients with atopic dermatitis [80]. Chronic lesions also express moderate levels of the T1 cell cytokine IFN- $\gamma$, while IL-17 can hardly be detected $[76,90]$.

The aforementioned cytokine pattern is also the reason for the deficient epidermal production of anti-microbial proteins (AMPs) and antiviral proteins (AVPs) atopic dermatitis patients show (Fig. 3). In fact, high T2 cytokine/low IL-17 levels result in low AMP production by keratinocytes [91-93], while lacking expression of the T17 cytokine IL-29 is associated with impaired keratinocyte AVP expression [94] (see also "Common T cell-related disorder"). Low AMP levels in the barrierdisturbed skin of atopic dermatitis patients predestinate for atypical cutaneous colonization with Staphylococcus aureus, penetration of microbial pathogens and their immunostimulating constituents into the skin, and infections with this pathogen [95-99]. Interestingly, subclinical $S$. aureus colonization also occurs in non-lesional skin of patients, correlating with disturbed skin barrier function and disease extent $[99,100]$. Atopic dermatitis patients also show an increased risk of developing skin infections with viral pathogens, including human papillomavirus, herpes simplex virus (HSV), and molluscum contagiosum virus $[95,98]$. In rare cases, HSV infection may spread and

Fig. 3 Immunopathophysiology of atopic dermatitis

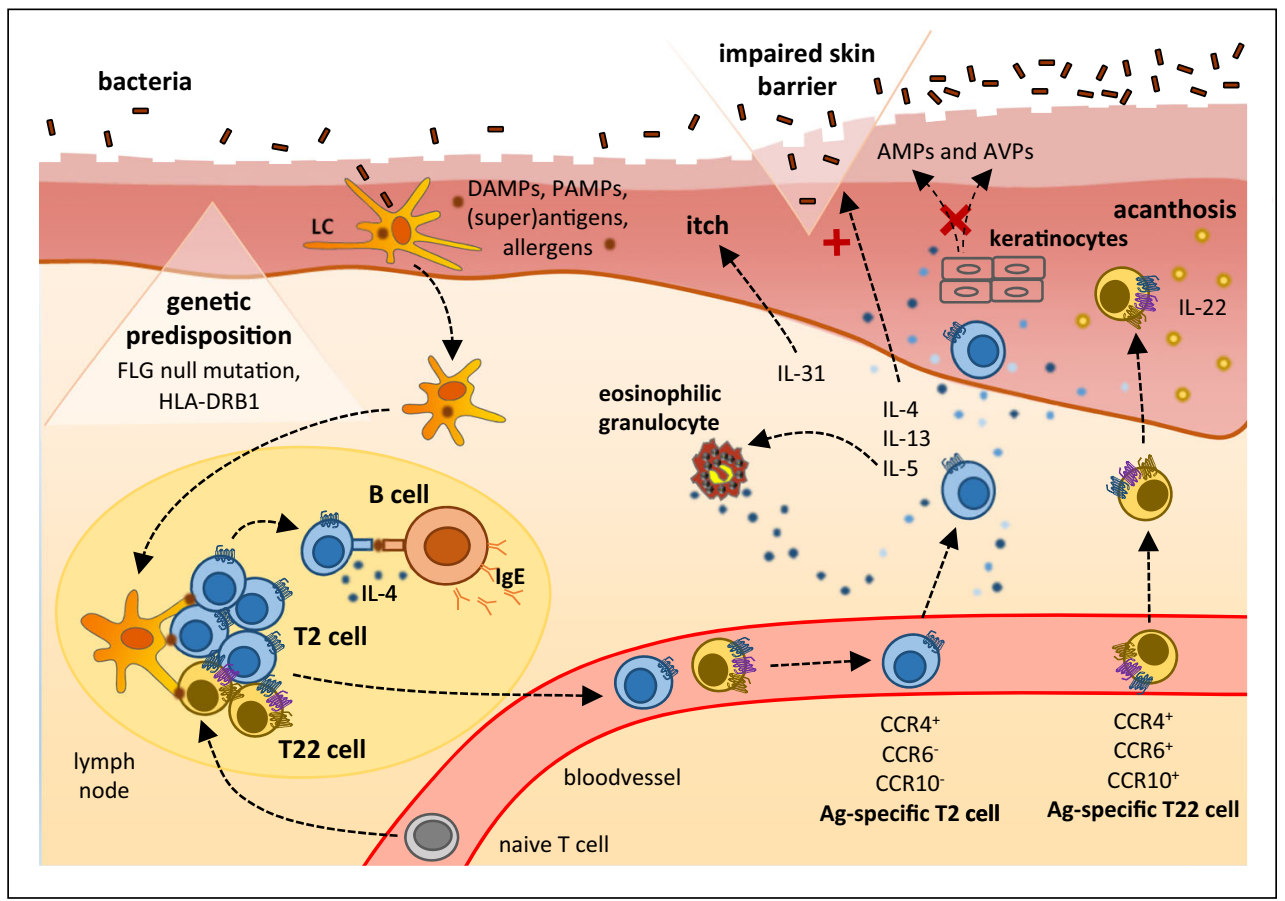


cause Ekzema herpeticatum [101]. Importantly, the impaired skin barrier function also promotes epicutaneous sensitization to allergens and may explain the high allergy frequency in affected patients.

\section{Immunopathology-based therapy of atopic dermatitis}

Classically, topical corticosteroids and, for more severe disease, systemic immunosuppressive agents are used. Since 2016, topical phosphodiesterase inhibitors such as crisaborole [102] (for the treatment of mild to moderate disease) are approved. More recently, the first biologic for treating atopic dermatitis, namely dupilumab, was introduced [103]. This antibody targets the IL-4/IL-13 receptor and was approved in 2017 for the treatment of moderate to severe disease (Table 2). A large number of other biologics for the treatment of atopic dermatitis are under development (Table 3).

\section{T17 cells, T22 cells, and psoriasis}

\section{Clinical and histological picture of psoriasis}

With a prevalence of $2-3 \%$ in Western countries, psoriasis is another very common T cell-mediated skin disease [104]. Psoriasis manifests with sharply demarcated, raised, erythematous plaques covered by silvery scales. Lesions preferentially

Table 2 Approved biologics for the treatment of atopic dermatitis, psoriasis, and melanoma

\begin{tabular}{lll}
\hline Indication & Target & Drug name \\
\hline AD & IL-4R $\alpha$ & Dupilumab \\
Pso, PsA & TNF- $\alpha$ & Etanercept \\
Pso, PsA & TNF- $\alpha$ & Infliximab \\
Pso, PsA & TNF- $\alpha$ & Adalimumab \\
PsA & TNF- $\alpha$ & Golimumab \\
Pso, PsA & TNF- $\alpha$ & Certolizumab-pegol \\
PsA & CD80/CD86 & Abatacept \\
Pso, PsA & p40 & Ustekinumab \\
Pso, PsA & IL-17 & Secukinumab \\
Pso, PsA & IL-17 & Ixekizumab \\
Pso & IL-17R & Brodalumab \\
Pso & p19 & Guselkumab \\
Pso & p19 & Tildrakizumab \\
Melanoma & CTLA-4 & Ipilimumab \\
Melanoma & PD-1 & Pembrolizumab \\
Melanoma & PD-1 & Nivolumab \\
Melanoma & IFN- $\alpha$ R & IFN- $\alpha-2 b$ \\
Melanoma & IL-2R & IL-2 \\
\hline
\end{tabular}

AD atopic dermatitis, Pso psoriasis, PSA psoriasis arthritis develop in mechanically stressed areas such as the extensor sides of the arms and legs, the sacral region, and the head [105].

Microscopically, psoriatic skin lesions show a massively thickened epidermis. This is the result of a substantial elongation of the epidermal rete ridges and an increased stratum corneum (hyperkeratosis). Furthermore, a reduced stratum granulosum and presence of nuclear remnants in the stratum corneum (parakeratosis) are typical features. Mechanistically, these changes are based on excessive proliferation of basal keratinocytes (TA cells) and an impaired cornification process of the keratinocytes of the upper epidermal layers [106]. In the dermis, dilatated blood capillaries greatly extend between epidermal rete ridges toward the skin surface [107]. The massive immune cell infiltration, which is most prominent in the dermis but not restricted to it, predominantly consists of monocytes/macrophages, dendritic cells, and T cells [108]. There are also accumulations of partially netose-forming neutrophilic granulocytes in the stratum corneum, called Munro's microabscesses [109].

Interestingly, inflammation in psoriasis is not restricted to the skin. More than $20 \%$ of patients show involvement of the joints [110]. In addition, the prevalence of colitis is increased, and metabolic and cardiovascular alterations lead to a shortened life expectancy in the patients [111, 112].

\section{Immunopathophysiology of psoriasis}

Both genetic and extern/lifestyle factors are involved in the development of psoriatic skin alterations (Fig. 4). Approximately $75 \%$ percent of patients report a positive family history [113]. A great proportion of patients carry the MHC haplotype HLA-Cw6 [113, 114], which has been correlated with certain clinical characteristics and therapeutical outcome in patients with psoriasis [115]. In addition, proposed autoantigens in psoriasis like the cathelicidin-derived peptide LL-37 and the melanocytic protein ADAMTSL5 were demonstrated to have T cell-stimulatory activity in HLA-Cw6carrying patients [115]. Furthermore, there are associations with genes related to the keratinocyte terminal differentiation, antimicrobial defense, and the T17 cell pathway [116]. Regarding the latter (see also below), psoriasis has been linked for example to polymorphisms within IL12B, IL23A, IL23R, and, in some patients with a special psoriasis subtype, pustular psoriasis, also $I L 36 R N$. Moreover, there are associations with variants in REL, TYK2, RUNX3, STAT3, and TRAF3IP2 [115]. Exogenous triggering factor for psoriasis involves mechanical skin trauma, streptococcal infections, and certain drugs [115].

The central pathways crucial to psoriasis pathogenesis involve T17 and T22 cells, whose mediators and upstream and downstream molecules are highly present in the lesions (Fig. 4). In addition to T cells (CD4+ and CD8+), type 3 innate lymphoid cells play a role as producers of IL-17 and IL-22 $[117,118]$. One of the most relevant cytokines promoting 
Table 3 Biologics under development for the treatment of atopic dermatitis

\begin{tabular}{|c|c|c|c|c|c|c|}
\hline Target(s) & Drug name & Phase & Company & Trial ID & $\begin{array}{l}\text { Study } \\
\text { start }\end{array}$ & Status \\
\hline $\operatorname{IgE}$ & Ligelizumab & 2 & Novartis & NCT01552629 & 1.2012 & Completed \\
\hline $\operatorname{IgE}$ & Anti-CemX & 2 & Fountain BioPharma & NCT03758716 & 11.2018 & Active, not recruiting \\
\hline IgE, Fc $\gamma$ RIIb & $\mathrm{XmAb7195}$ & 1 & Xencor & NCT02148744 & 9.2015 & Completed \\
\hline IL- $1 \alpha$ & Bermekimab & 2 & XBiotech & NCT03496974 & 11.2018 & Recruiting \\
\hline IL-5 & Mepolizumab & $1 / 2$ & GlaxoSmithKline & NCT03055195 & 3.2017 & Terminated \\
\hline IL-5RA & Benralizumab & 2 & AstraZeneca & NCT03563066 & 9.2018 & Not yet recruiting \\
\hline $\begin{array}{l}\text { IL-12/IL-23 } \\
\quad(\mathrm{p} 40)\end{array}$ & Ustekinumab & 2 & Janssen Pharmaceutical K.K. & NCT01945086 & 9.2013 & Completed \\
\hline $\mathrm{IL}-13$ & Tralokinumab & 3 & LEO Pharma & NCT03526861 & 6.2018 & Recruiting \\
\hline IL-13 & Lebrikizumab & 2 & Dermira & NCT03443024 & 1.2018 & Active, not recruiting \\
\hline IL-17A & Secukinumab & 2 & Novartis & NCT02594098 & 11.2015 & Completed \\
\hline IL-17C & MOR106 & 2 & Galapagos NV & NCT03568071 & 4.2018 & Recruiting \\
\hline IL-22 & Fezakinumab & 2 & Pfizer & NCT01941537 & 10.2013 & Active, not recruiting \\
\hline IL-22R & ARGX-112 & 1 & LEO Pharma & NCT03514511 & 5.2018 & Recruiting \\
\hline IL-23 & Risankizumab & 2 & Abbvie & NCT03706040 & 12.2018 & Recruiting \\
\hline IL-31 & BMS-981164 & 1 & Bristol-Myers Squibb & NCT01614756 & 7.2012 & Completed \\
\hline IL-31RA & Nemolizumab & 2 & Galderma & NCT03100344 & 6.2017 & Completed \\
\hline IL-33 & REGN3500 & $2 b$ & Sanofi/Regeneron Pharmaceuticals & NCT03738423 & 11.2018 & Recruiting \\
\hline IL-33 & Etokimab & 2 & AnaptysBio, Inc. & NCT03533751 & 5.2018 & Recruiting \\
\hline OX40 & KHK4083 & 2 & $\begin{array}{l}\text { Kyowa Hakko Kirin Pharmaceutical } \\
\text { Development, Inc. }\end{array}$ & NCT03703102 & 10.2018 & Recruiting \\
\hline OX40 & GBR 830 & 2 & Glenmark Pharmaceuticals & NCT03568162 & 5.2018 & Recruiting \\
\hline OX40 & KY1005 & 2 & Kymab Limited & NCT03754309 & 12.2018 & Recruiting \\
\hline ST2 & MSTT1041A & 2 & Roche & NCT03747575 & 1.2019 & Recruiting \\
\hline ST2 & CNTO 7160 & 1 & Janssen Research \& Development, LLC & NCT02345928 & 8.2014 & Completed \\
\hline TSLP & Tezepelumab & $2 b$ & AstraZeneca & NCT03809663 & 1.2019 & Not yet recruiting \\
\hline TSLPR & MK-8226 & 1 & Merck Sharp \& Dohme Corp. & NCT01732510 & 12.2012 & $\begin{array}{l}\text { Terminated (business } \\
\text { reasons) }\end{array}$ \\
\hline $\begin{array}{l}\text { Undisclosed } \\
\text { target }\end{array}$ & REGN846 & $1 / 2$ & Sanofi/Regeneron Pharmaceuticals & NCT01605708 & 6.2012 & Terminated \\
\hline $\begin{array}{l}\text { Undisclosed } \\
\text { target }\end{array}$ & LY3454738 & 1 & Eli Lilly and Company & NCT03750643 & 11.2018 & Recruiting \\
\hline
\end{tabular}

Source: Clinicaltrials.gov. Clinical trials that started after January 2012 are shown

IL-17 and IL-22 expression by immune cells is IL-23. This heterodimeric cytokine is highly expressed in psoriatic skin. IL-23 inhibits IL-10 production by T17 cells and instead induces an inflammatory T17 phenotype [119]. Moreover, TNF- $\alpha$, primarily secreted by T17 cells, T22 cells, and macrophages, as well as the T1 cell mediator IFN- $\gamma$ are abundant in the psoriatic skin [120]. In sharp contrast, IL-4 is not found in psoriatic lesions.

Main target cells of IL-17A, IL-17F, and IL-22 in the skin are keratinocytes, although IL-17 effects were also described for immune cells and other tissue cells. In keratinocytes, IL-17 induces the production of selected chemokines (such as CCL20, which attracts T17 cells, T22 cells, and DCs, as well as CXCL1, CXCL2, CXCL5, and CXCL8, which all attract neutrophilic granulocytes) and other cytokines (such as IL-6, the granulocyte-activating cytokine G-CSF, and IL-19) in the skin. Presumably, IL-17 alone causes only moderate cellular responses while mainly synergizing with TNF- $\alpha$, and IL-22 [121-127]. Together with IL-22, IL-17 induces the production of AMPs and therefore plays an essential role in the remarkable immune defense of the psoriatic plaque against extracellular bacteria and fungi [54, 126, 128-130]. In fact, it is a peculiarity of psoriasis patients that the impairment of the skin barrier function is not associated with an increased skin infection risk $[95,96]$. Apart from its function in antibacterial defense, IL-22 is the main mediator of the impaired keratinocyte cornification process in psoriasis. IL-22 reduces the expression of molecules like filaggrin required for the terminal differentiation of keratinocytes [89]. The consequences of the IL-22-mediated inhibition of 
Fig. 4 Immunopathophysiology of psoriasis

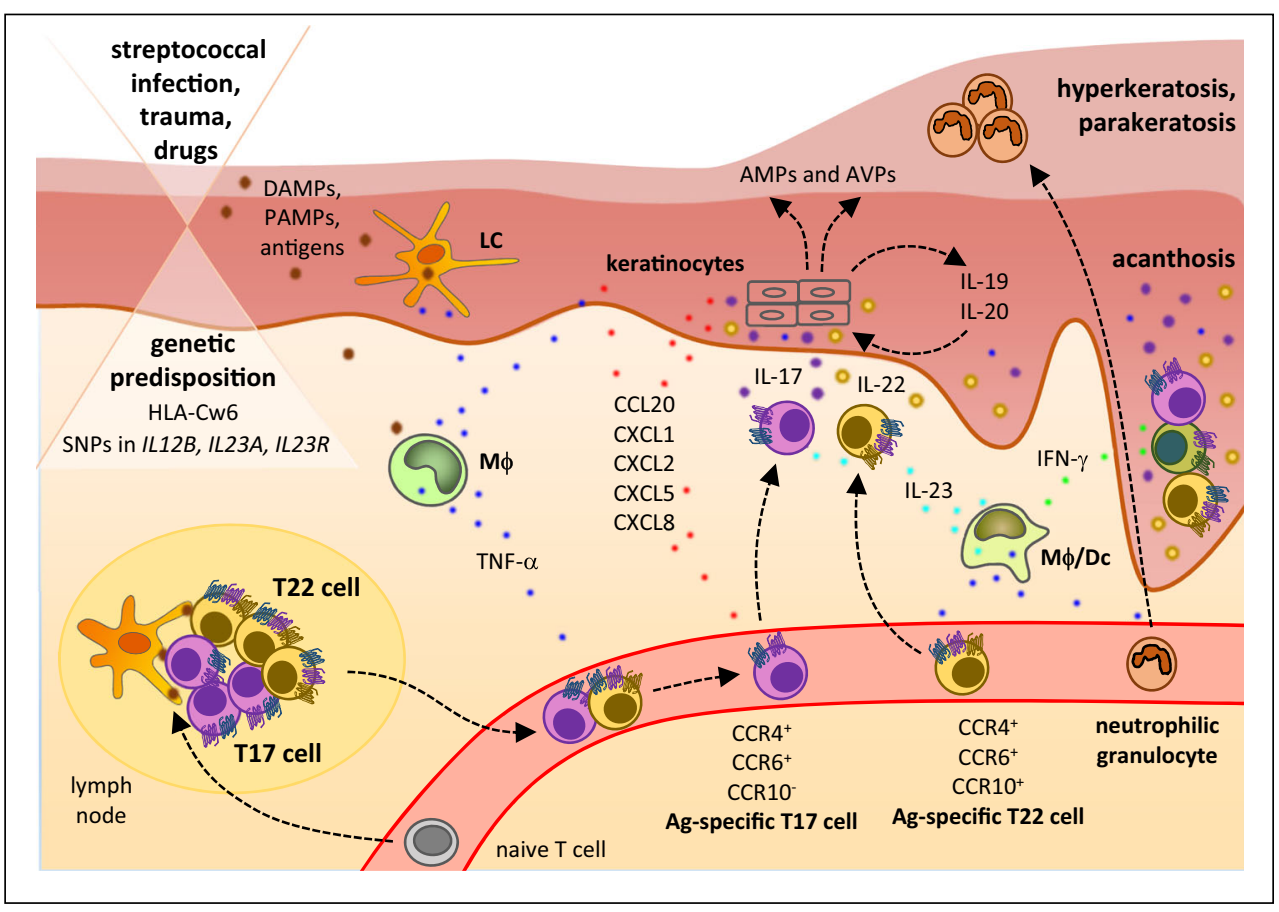

the keratinocyte terminal differentiation are reflected by a marked epidermal thickening and hypogranulosis of reconstituted three-dimensional human epidermis models and IL-22-transgenic mice [88]. Apart from the direct effects of IL-22, this mediator also acts via the induction of IL-20 in keratinocytes, which, by partially using the same receptor (IL-22R1), can exert IL-22-like effects [131]. It should be noted that the activity of IL-22 is regulated by IL-22 binding protein [132]. In psoriasis patients, the expression of this natural inhibitor is downregulated in non-lesional skin, and such downregulation is associated with an increased sensitivity of the skin to the pathogenetic action of IL-22 [133]. Increased levels of the T1 cell cytokine IFN- $\gamma$ may support the activation of dermal endothelia to allow infiltration of immune cells from the bloodstream into the psoriatic lesion [134]. IFN- $\gamma$ further induces chemokines attracting T1 cells including CXCR10 [135] and upregulates the expression of MHC molecules on both tissue and antigen-presenting immune cells [134]. The pleiotropic and highly inflammatory cytokine TNF- $\alpha$ induces a wide range of immune cell-attracting chemokines and contributes to endothelial activation, two functions necessary for immune cell infiltration [136]. Many effects of cytokines are enhanced in the presence of TNF- $\alpha[121,122,125]$, arguing for a central role of this cytokine in skin inflammation.

Another mediator, which can be produced by $\mathrm{T} 17$ cells in psoriasis, is IL-29. IL-29 is able to inhibit the replication of viruses via the induction of AVPs [137] and seems to be responsible for the high resistance of psoriatic epidermis toward viral superinfections [94].

\section{Immunopathology-based therapy of psoriasis}

The excellent knowledge about the specific cytokine pathways involved in psoriasis pathogenesis has allowed the tremendous success in the development of innovative drugs for the treatment of moderate to severe psoriasis [108]. These include therapeutic antibodies that neutralize IL-17 and IL23 as well as TNF- $\alpha$ (Table 2). A broad range of further drugs is under development $[138,139]$.

\section{Treg cells and melanoma}

\section{Clinical and histological picture of melanoma}

The worldwide incidence of cutaneous melanoma has been increasing annually at a more rapid rate compared with any other type of cancer. In 2012, 232,000 new cases of melanoma and 55,000 related deaths were registered worldwide, ranking 15th among most common cancers [140]. About $90 \%$ of melanoma cases are diagnosed as primary tumors without evidence of metastasis, and their 10-year survival is between 75 and $80 \%$ [141]. Metastases, which can develop either via the lymphatic or the hematogenous route, are the main cause of death in melanoma patients [142]. Disease is subclassified to estimate prognosis and determine therapeutic interventions. This classification considers TNM criteria together with tumor thickness, ulceration, mitotic figures, and microscopic satellites of the primary tumor.

UV light radiation from sunlight, in particular the UV-B spectrum, is the main environmental risk factor for melanoma skin cancer development [143]. Melanoma in chronically sun- 
exposed skin usually manifests in older-aged individuals and has a high tumor mutational burden related to UV exposure. The main genetic drivers are mutations in the genes encoding B-Raf proto-oncogene (BRAF), neurofibromin 1 (NF1), $N R A S$, and others. Melanomas associated with intermittently sun-exposed skin cases arise in younger-aged individuals and are usually associated with the $\mathrm{BRAF}^{\mathrm{V} 600 \mathrm{E}}$ mutation and a lower mutational load [144, 145]. Up to $90 \%$ of melanomas exhibit an aberrant MAPK pathway activation as central step in melanoma development [146]. Furthermore, SNPs in genetic loci that associate with the risk for developing malignant melanoma have also been reported in patients. Examples of such genes are $C D K N 2 A, C D K 4$, and others. These genetic findings helped to establish small molecular inhibitors of signaling pathways that promote melanoma.

\section{Immunopathophysiology of melanoma}

Melanoma is deemed one of the most immunogenic types of cancer. In fact, several melanoma-specific antigens have been identified and large numbers of melanoma-specific antibodies and functional lymphocytes are present in patients with melanoma [147]. Moreover, spontaneous regression of melanoma with simultaneous onset of vitiligo has been reported [148] and metastatic melanoma responds to immune-stimulating agents, such as IFNs and IL-2 as well as the novel immune checkpoint inhibitors blocking cytotoxic $\mathrm{T}$ lymphocyteassociated antigen-4 (CTLA-4) and PD-1 [149-151]. The major base for the strong immunogenicity of melanoma is its often very high (UV-driven) tumor mutational burden, which allows for the creation of neoantigens recognizable as "nonself" by host immune cells [152, 153]. Accordingly, strong immune cell infiltration is an established positive prognostic parameter in advanced melanoma $[154,155]$. Despite the immunogenicity of melanoma and induction of tumor-specific immune responses [156], current immunotherapies show limited efficacy and are restricted to subpopulations of patients with advanced melanoma. It has been suggested that several negative factors hinder antitumor immune activities. These include (i) immune-suppressive cells like Treg cells and myeloid-derived suppressive cells, (ii) anti-inflammatory cytokines like tumor growth factor (TGF)- $\beta$ and IL-10, (iii) defective antigen presentation by tumor cells because of antigen expression loss and antigen processing defects, (iv) immune inhibitory molecules like CTLA-4 and PD-1, and (v) amino acid-catabolizing enzymes like arginase and indoleamine-2-3 dioxygenase (IDO) [157].

In both animal models and human beings, Treg cells infiltrate into the tumor microenvironment, dampening immune responses to tumor cells [158-160]. Cell-to-cell contact, production of immune-suppressive cytokines like IL-10 and TGF-B, competing for growth factors with other effector cells, and modification of APCs are the four main strategies how
Treg cells apply to exert their inhibitory effects $[161,162]$. As most tumor antigens are normal self-antigens, such tumors could induce tumor-specific Treg cells, suppressing effective antitumor responses $[163,164]$. In animal models of melanoma, transient Treg cell depletion induces immune responses against tumor and improves survival, indicating the importance of these cells [165]. Wang et al. were the first to isolate Treg cells that recognize epitopes from the tumor-associated antigen LAGE-1 from patients with melanoma, providing evidence for the relevance of this mechanism also in the melanoma setting [166]. Tumor-specific Treg cells that can recognize a broad range of melanoma-associated antigens and neoantigens can be detected in the tumors and in the blood of melanoma patients $[167,168]$. Fourcade et al. showed that the same melanoma-associated antigens can stimulate both $\mathrm{Th}$ and Treg cells [169]. As a consequence, immunotherapeutic vaccinations with melanoma-associated antigens in patients with melanoma can result in expansion of both induced and naturally occurring melanoma-associated Treg cells [170].

Numerous researches have indicated increased numbers of Treg cells not only in the local tumor microenvironment including primary and metastatic lesions but also in peripheral blood of subjects with metastatic melanoma, as well as in affected draining lymph nodes $[159,160]$. Treg cell accumulation in the tumor microenvironment was reported to be predictive of reduced survival of melanoma patients [171]. Subsequently, several other retrospective studies demonstrated the correlation between Treg cell infiltration and prognosis of melanoma patients [172]. Vice versa, the parameter that best correlates with favorable clinical outcome and survival of melanoma patients seems to be the ratio of CD8-positive effector T cells to Treg cells in the tumor microenvironment [173]. The chemokine CCL22 is known to mediate CCR $4^{\text {high }}$ Treg cell trafficking into tumors [174]. The CCR4-mediated Treg cell attraction into melanomas, however, seems to be caused by the alternative CCR4 ligand CCL2 [175].

Immunosuppressive factors that are locally secreted by melanomas, such as TGF- $\beta$ and IL-10, could promote both expansion of naturally occurring Treg cells and de novo generation of induced Treg cells [165]. Likewise, molecular mechanisms of tumor immunosuppression mediated by IDO have a direct anergic effect on effector $T$ cells and enhance local Treg cell-mediated immunosuppression. Moreover, expression of IDO on tumorinfiltrating APCs stimulates the conversion of conventional T cells to Treg cells [176]. Upregulation of IDO expression in melanoma lymph-node metastases is associated with an increased number of tumor-infiltrating Treg cells and consequently shorter patient survival [177]. Interestingly, very recently, it has been reported in an inducible autochthonous model of melanoma that the expression of the oncogenic $\mathrm{BRAF}^{\mathrm{V} 600 \mathrm{E}}$ mutation in melanocytes resulted in nevus formation, CCR4 induction, and 
Treg cell recruitment [178]. This suggests the $\mathrm{BRAF}^{\mathrm{V} 600 \mathrm{E}}$ signaling is sufficient to recruit the Treg cells to melanomas and might add an additional mechanism for explaining the therapeutic activity of BRAF inhibition in patients with metastatic melanoma (see below). The pathophysiology of melanoma is depicted in Fig. 5.

\section{Immunopathology-based therapy of melanoma}

As mentioned above, the majority of patients with newly diagnosed melanoma have early-stage disease, for which surgical excision represents the treatment of choice and is curative in the majority of cases [179]. However, approximately $10 \%$ of melanoma cases are diagnosed at an advanced stage and are unresectable or already metastatic. Due to the known immunogenicity of melanoma, experimental immunotherapy had a prominent position in the treatment of melanoma for decades.

Collected data from several clinical trials evaluating the efficacy of recombinant IL-2 therapy in the 1980s showed that a small fraction of melanoma patients experienced durable complete responses. Based on these results, in 1998, the FDA approved IL-2 for the treatment of unresectable melanoma [180] (Table 2). IL-2 is a key regulator in supporting proliferation and homeostasis of effector $T$ cells but is also crucial for the development of Treg cells, therefore simultaneously leading to increased numbers of Treg cells in melanoma patients [167, 181]. However, IL-2 was also described to mask the suppressive function of Treg cells on effector T cell proliferation [182].
Since Treg cell-mediated immunosuppression is generally deemed one of the main hurdles for cancer immunotherapy, various approaches for depletion and/or modulation of Treg cells (cyclophosphamide, denileukin diftitox, anti-CD25 antibody (daclizumab), anti-CD25 immunotoxin) have been characterized and tested with different clinical outcome. New such experimental approaches include an anti-CCR4 antibody for Treg cell depletion as well as an agonistic antibody against the glucocorticoid-induced tumor necrosis factor receptor (GITR) for modulation of Treg cell activity [159, 160, 165].

The main treatment for melanoma patients in the early stages is surgical resection. For a long period, the only treatments for patients with metastatic melanoma included chemotherapy with dacarbazine and some other agents as well as immunotherapy with high doses of IL-2. In the last 10 years, MAP kinase pathway-targeted therapies (BRAF and MEK inhibitors) and immune checkpoint inhibitors blocking CTLA-4 and PD-1 have revolutionized the management of advanced melanoma and significantly prolonged patient survival $[149,151]$ (Table 2).

In $\mathrm{BRAF}^{\mathrm{V} 600 \mathrm{E}}$-mutated melanoma, the combination of BRAF and MEK inhibitors has led to high response rates $(70 \%)$ and rapid response induction and symptom control, with a significant prolongation of progression-free survival $[183,184]$. Interestingly, it was reported that BRAF inhibition could promote the immune response to melanoma [185].

CTLA-4 is an inhibitory receptor that is constitutively expressed by Treg cells. CTLA- 4 binds to CD80 and CD86 on APCs and acts as a key negative regulator of peripheral $\mathrm{T}$ cell proliferation and function. In mice
Fig. 5 Immunopathophysiology of melanoma

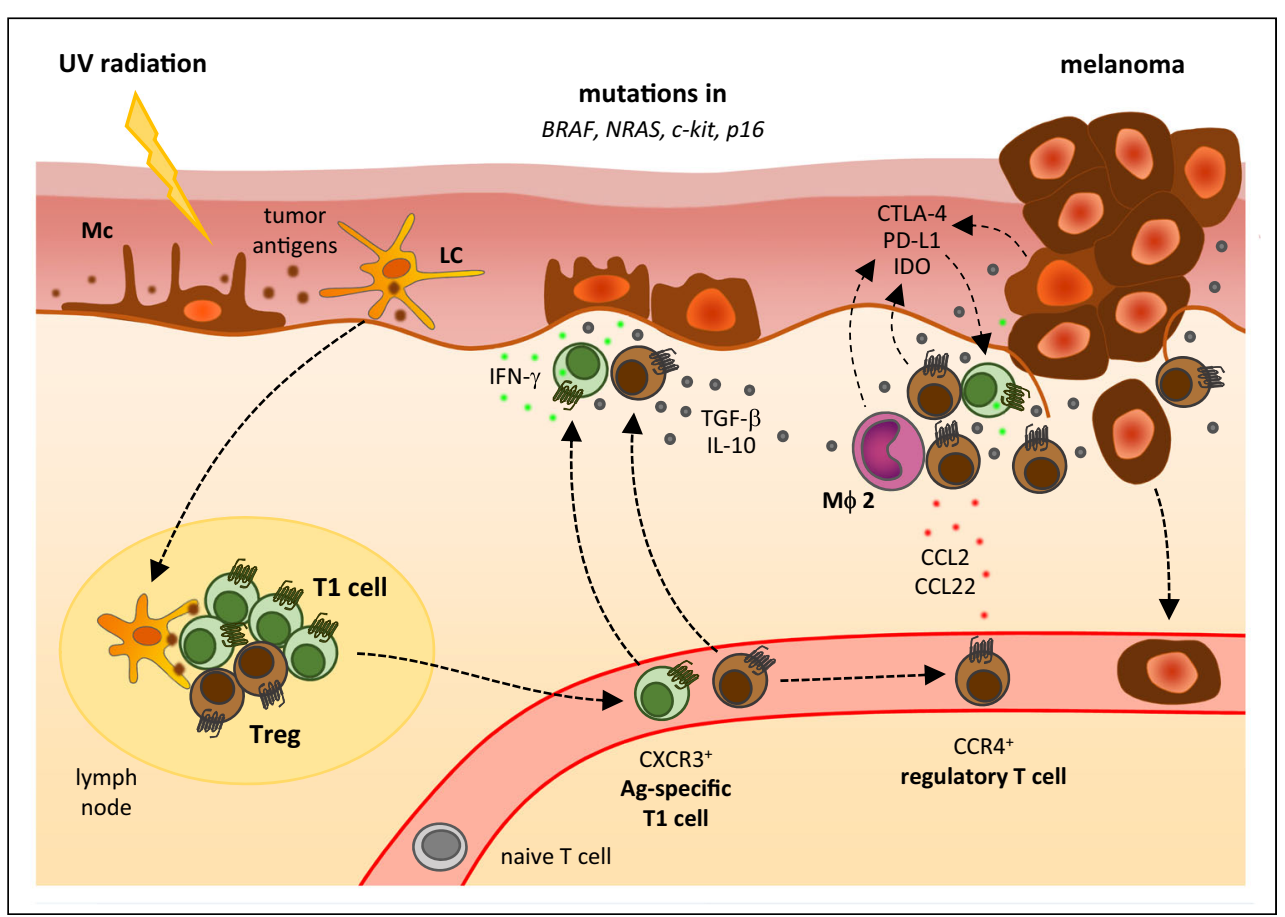


models, treatment with monoclonal anti-CTLA-4 antibodies increased the local infiltration of cytotoxic $\mathrm{T}$ cells while dramatically reducing Tregs at the tumor site [173, 186]. The human anti-CTLA-4 antibody ipilimumab was demonstrated to be effective in a phase III clinical trial and received FDA approval for treating metastatic melanoma in 2011 [187]. Remarkably, meta-analyses demonstrated the durability of long-term survival in a significant number of ipilimumab-treated patients [188]. Whether there is a depletion or reduction of Treg cells in melanoma microenvironment as mechanism of therapeutic antiCTLA-4 antibodies in the patients is still under debate [189-192]. The PD-1 receptor is expressed on Treg cells and activated effector lymphocytes. It binds to PD-L1 and PD-L2, acts as a T cell co-inhibitory molecule, and suppresses $\mathrm{T}$ cell activation. Nivolumab is a high-affinity anti-PD-1 monoclonal antibody that inhibits the binding between the PD-1 receptor and its ligands PD-L1 and PDL2. Nivolumab was approved (2014) by the FDA for the treatment of patients with metastatic melanoma [193]. Pembrolizumab, another anti-PD-1 antibody, was approved by the FDA in 2015 for the treatment of advanced melanomas [184]. Interestingly, a very recent paper suggests that PD-1 blockade can decrease the suppressive function of Tregs in vitro and that the therapeutic benefit of nivolumab in melanoma patients corresponds to a decreased suppressive function of blood Treg cells [194]. Moreover, a quite current paper described significantly increased responses to anti-PD1 in aged melanoma patients and correlated this with higher CD8+ effector /FoxP3+ Treg cell ratios in the tumor microenvironment in this population [195]. Interestingly, in some patients with successful anti-tumor response by checkpoint inhibitors, vitiligo-like depigmentation can be observed.

\section{Conclusion}

Chronic T cell-mediated skin diseases represent a major health economy problem worldwide. Pathogenetically, these diseases are based on different mechanisms that are closely related to effector functions of respective $\mathrm{T}$ cell subtypes. Activity of T1 cells leads to destruction of cells expressing antigens recognized by these T cells. For example, when respective antigens are carried by melanocytes, the stimulation of the antigen-specific $\mathrm{T} 1$ cells results in pigment-free skin patches that characterize vitiligo. The activation of $\mathrm{T} 2$ cells leads to IL-4, IL-5, and IL-13 secretion, provoking skin barrier alteration, immune cell infiltration into skin, and itch as observed in atopic dermatitis. The stimulation of T17 and T22 cells is associated with highly increased production of IL-17, IL-22, and TNF- $\alpha$ that promote the proliferation of keratinocytes and alter their terminal differentiation. These cellular changes result in sharply demarcated, reddishcolored raised plaques with superficial silvery scaling as observed in psoriasis. In many other immune-mediated skin diseases, the exact phenotype of disease-responsible $\mathrm{T}$ cells is less clear. Examples are diseases such as lichen planus, hidradenitis suppurativa, or pemphigus. Apart from the dysregulated activity of T1, T2, T17, and T22 effector T cells, an increased activity of Treg cells can be involved in the development of skin diseases. An impressive example for this is skin melanoma, a malignant tumor of melanocytic origin, which presents as hyper-pigmented maculae or nodules. In that disease, local Treg cell-mediated immunosuppression is thought to be responsible for the dampened immune response (mainly T1) to the tumor cells.

The understanding of the immunopathogenetic mechanisms involved in skin diseases opens up great opportunities for the development of targeted therapeutic approaches for the respective patients. In fact, while, on the one hand, our knowledge of T cell biology has allowed the development of efficient strategies to control, e.g., psoriasis, the great success of these strategies in dermatology has, vice versa, decidedly contributed to the understanding of T cell biology and the pathways they are involved in. Further studies in immunodermatology are needed to improve the treatment options for many other inflammatory and neoplastic skin diseases beyond vitiligo, psoriasis, atopic dermatitis, and melanoma.

Acknowledgments The authors would like to acknowledge Julia Triebus for her assistance in manuscript editing and picture production as well as Katrin Witte and Georgios Kokolakis for their help with the tables and manuscript proofreading.

Funding information The authors acknowledge the support by the Deutsche Forschungsgemeinschaft (DFG) FOR 2497/TP02 (GH133/2-1 to Kamran Ghoreschi), the German Federal Ministry of Education and Research (http://www.bmbf.de/; grant 01ZX1312A to Kerstin Wolk and RobertSabat), and Novartis Pharma GmbH (to Charité Universitätsmedizin Berlin/Robert Sabat).

\section{Compliance with ethical standards}

Conflict of interest $\mathrm{KG}$ has been a consultant, lecturer, or investigator for AbbVie Deutschland GmbH \& Co. KG, Almirall, Biogen IDEC GmbH, Boehringer Ingelheim Pharma GmbH \& Co. KG, Celgene GmbH, Eli Lilly and Company, Janssen-Cilag GmbH, MSD Sharp \& Dohme, Novartis Pharmaceuticals, Pfizer Deutschland $\mathrm{GmbH}$, and Roche.

RS has received research grants or honoraria for participation in advisory boards, clinical trials or as speaker for one or more of the following: AbbVie Inc., AbbVie Deutschland GmbH \& Co. KG, Bayer Schering Pharma AG, Biogen IDEC GmbH, Boehringer Ingelheim Pharma GmbH \& Co. KG, Celgene GmbH, Celgene International II Sàrl, Charité Research Organisation GmbH, Dr. Willmar Schwabe $\mathrm{GmbH} \&$ Co. KG, Flexopharm GmbH \& Co. KG, Generon Corporation Ltd., Janssen-Cilag GmbH, Novartis Pharma GmbH, Parexel International GmbH, Pfizer Deutschland $\mathrm{GmbH}$, SanofiAventis Deutschland GmbH, TFS GmbH, UCB Biopharma SPRL.

$\mathrm{KW}$ has been a consultant, lecturer, or investigator for AbbVie Deutschland GmbH \& Co. KG, Bayer Schering Pharma AG, Celgene 
GmbH, Celgene International II Sàrl, Generon Corporation Ltd., JanssenCilag GmbH, Novartis Pharma GmbH, Sanofi-Aventis Deutschland $\mathrm{GmbH}$, and UCB Biopharma SPRL.

Open Access This article is distributed under the terms of the Creative Commons Attribution 4.0 International License (http:// creativecommons.org/licenses/by/4.0/), which permits unrestricted use, distribution, and reproduction in any medium, provided you give appropriate credit to the original author(s) and the source, provide a link to the Creative Commons license, and indicate if changes were made.

\section{References}

1. Fuchs E (2016) Epithelial skin biology: three decades of developmental biology, a hundred questions answered and a thousand new ones to address. Curr Top Dev Biol 116:357-374

2. Weidinger S, Beck LA, Bieber T, Kabashima K, Irvine AD (2018) Atopic dermatitis. Nat Rev Dis Primers 4:1

3. Wolk K, Witte K, Sabat R (2010) Interleukin-28 and interleukin29: novel regulators of skin biology. J Interf Cytokine Res 30: 617-628

4. Fuchs E (2008) Skin stem cells: rising to the surface. J Cell Biol 180:273-284

5. Sabat R, Wolk K (2011) Research in practice: IL-22 and IL-20: significance for epithelial homeostasis and psoriasis pathogenesis. J Dtsch Dermatol Ges 9:518-523

6. Sabat R, Philipp S, Hoflich C, Kreutzer S, Wallace E, Asadullah K, Volk HD, Sterry W, Wolk K (2007) Immunopathogenesis of psoriasis. Exp Dermatol 16:779-798

7. Gebhardt T, Palendira U, Tscharke DC, Bedoui S (2018) Tissueresident memory $\mathrm{T}$ cells in tissue homeostasis, persistent infection, and cancer surveillance. Immunol Rev 283:54-76

8. Parisi R, Webb RT, Kleyn CE, Carr MJ, Kapur N, Griffiths CEM, Ashcroft DM (2019) Psychiatric morbidity and suicidal behaviour in psoriasis: a primary care cohort study. Br J Dermatol 180:108-115

9. Kurek A, Johanne Peters EM, Sabat R, Sterry W, SchneiderBurrus S (2013) Depression is a frequent co-morbidity in patients with acne inversa. J Dtsch Dermatol Ges 11:743-749 50

10. Weidinger S, Novak N (2016) Atopic dermatitis. Lancet 387: 1109-1122

11. Richard MA, Corgibet F, Beylot-Barry M, Barbaud A, Bodemer C, Chaussade V, D'Incan M, Joly P, Leccia MT, Meurant JM, Petit A, Geffroy BR, Sei JF, Taieb C, Misery L, Ezzedine K (2018) Sexand age-adjusted prevalence estimates of five chronic inflammatory skin diseases in France: results of the $<<$ OBJECTIFS PEAU > study. J Eur Acad Dermatol Venereol 32:1967-1971

12. Krangel MS (2003) Gene segment selection in V(D)J recombination: accessibility and beyond. Nat Immunol 4:624-630

13. Taniuchi I (2016) Views on helper/cytotoxic lineage choice from a bottom-up approach. Immunol Rev 271:98-113

14. Klein L, Kyewski B, Allen PM, Hogquist KA (2014) Positive and negative selection of the T cell repertoire: what thymocytes see (and don't see). Nat Rev Immunol 14:377-391

15. Sallusto F, Lenig D, Forster R, Lipp M, Lanzavecchia A (1999) Two subsets of memory $\mathrm{T}$ lymphocytes with distinct homing potentials and effector functions. Nature 401:708-712

16. Williams MA, Bevan MJ (2007) Effector and memory CTL differentiation. Annu Rev Immunol 25:171-192

17. Michie CA, McLean A, Alcock C, Beverley PC (1992) Lifespan of human lymphocyte subsets defined by CD45 isoforms. Nature 360:264-265

18. Buchholz VR, Flossdorf M, Hensel I, Kretschmer L, Weissbrich B, Graf P, Verschoor A, Schiemann M, Hofer T, Busch DH (2013)
Disparate individual fates compose robust CD8+ T cell immunity. Science 340:630-635

19. Picker LJ, Singh MK, Zdraveski Z, Treer JR, Waldrop SL, Bergstresser PR, Maino VC (1995) Direct demonstration of cytokine synthesis heterogeneity among human memory/effector $\mathrm{T}$ cells by flow cytometry. Blood 86:1408-1419

20. Jin HT, Anderson AC, Tan WG, West EE, Ha SJ, Araki K, Freeman GJ, Kuchroo VK, Ahmed R (2010) Cooperation of Tim-3 and PD-1 in CD8 T-cell exhaustion during chronic viral infection. Proc Natl Acad Sci U S A 107:14733-14738

21. Mackay LK, Minnich M, Kragten NA, Liao Y, Nota B, Seillet C, Zaid A, Man K, Preston S, Freestone D, Braun A, Wynne-Jones E, Behr FM, Stark R, Pellicci DG, Godfrey DI, Belz GT, Pellegrini M, Gebhardt T, Busslinger M, Shi W, Carbone FR, van Lier RA, Kallies A, van Gisbergen KP (2016) Hobit and Blimp1 instruct a universal transcriptional program of tissue residency in lymphocytes. Science 352:459-463

22. Kambayashi T, Laufer TM (2014) Atypical MHC class IIexpressing antigen-presenting cells: can anything replace a dendritic cell? Nat Rev Immunol 14:719-730

23. Iwasaki A, Medzhitov R (2010) Regulation of adaptive immunity by the innate immune system. Science 327:291-295

24. Pradeu T, Cooper EL (2012) The danger theory: 20 years later. Front Immunol 3:287

25. De Silva NS, Klein U (2015) Dynamics of B cells in germinal centres. Nat Rev Immunol 15:137-148

26. Szabo SJ, Kim ST, Costa GL, Zhang X, Fathman CG, Glimcher LH (2000) A novel transcription factor, T-bet, directs Th1 lineage commitment. Cell 100:655-669

27. Zheng W, Flavell RA (1997) The transcription factor GATA-3 is necessary and sufficient for Th2 cytokine gene expression in CD4 T cells. Cell 89:587-596

28. Ye P, Rodriguez FH, Kanaly S, Stocking KL, Schurr J, Schwarzenberger P, Oliver P, Huang W, Zhang P, Zhang J, Shellito JE, Bagby GJ, Nelson S, Charrier K, Peschon JJ, Kolls JK (2001) Requirement of interleukin 17 receptor signaling for lung CXC chemokine and granulocyte colony-stimulating factor expression, neutrophil recruitment, and host defense. J Exp Med 194:519-527

29. Acosta-Rodriguez EV, Rivino L, Geginat J, Jarrossay D, Gattorno M, Lanzavecchia A, Sallusto F, Napolitani G (2007) Surface phenotype and antigenic specificity of human interleukin 17 producing T helper memory cells. Nat Immunol 8:639-646

30. Eyerich S, Eyerich K, Pennino D, Carbone T, Nasorri F, Pallotta S, Cianfarani F, Odorisio T, Traidl-Hoffmann C, Behrendt H, Durham SR, Schmidt-Weber CB, Cavani A (2009) Th22 cells represent a distinct human $\mathrm{T}$ cell subset involved in epidermal immunity and remodeling. J Clin Invest 119:3573-3585

31. Schaerli P, Willimann K, Lang AB, Lipp M, Loetscher P, Moser B (2000) CXC chemokine receptor 5 expression defines follicular homing T cells with B cell helper function. J Exp Med 192:1553-1562

32. Breitfeld D, Ohl L, Kremmer E, Ellwart J, Sallusto F, Lipp M, Forster R (2000) Follicular B helper T cells express CXC chemokine receptor 5, localize to B cell follicles, and support immunoglobulin production. J Exp Med 192:1545-1552

33. Josefowicz SZ, Lu LF, Rudensky AY (2012) Regulatory T cells: mechanisms of differentiation and function. Annu Rev Immunol 30:531-564

34. Fontenot JD, Gavin MA, Rudensky AY (2003) Foxp3 programs the development and function of $\mathrm{CD} 4+\mathrm{CD} 25+$ regulatory $\mathrm{T}$ cells. Nat Immunol 4:330-336

35. Hori S, Nomura T, Sakaguchi S (2003) Control of regulatory T cell development by the transcription factor Foxp3. Science 299: 1057-1061

36. Trifari S, Kaplan CD, Tran EH, Crellin NK, Spits H (2009) Identification of a human helper $\mathrm{T}$ cell population that has 
abundant production of interleukin 22 and is distinct from $\mathrm{T}(\mathrm{H})$ 17, $\mathrm{T}(\mathrm{H}) 1$ and $\mathrm{T}(\mathrm{H}) 2$ cells. Nat Immunol 10:864-871

37. Bonecchi R, Bianchi G, Bordignon PP, D'Ambrosio D, Lang R, Borsatti A, Sozzani S, Allavena P, Gray PA, Mantovani A, Sinigaglia F (1998) Differential expression of chemokine receptors and chemotactic responsiveness of type $1 \mathrm{~T}$ helper cells (Th1s) and Th2s. J Exp Med 187:129-134

38. Maggi L, Santarlasci V, Capone M, Peired A, Frosali F, Crome SQ, Querci V, Fambrini M, Liotta F, Levings MK, Maggi E, Cosmi L, Romagnani S, Annunziato F (2010) CD161 is a marker of all human IL-17-producing T-cell subsets and is induced by RORC. Eur J Immunol 40:2174-2181

39. Cosmi L, De Palma R, Santarlasci V, Maggi L, Capone M, Frosali F, Rodolico G, Querci V, Abbate G, Angeli R, Berrino L, Fambrini M, Caproni M, Tonelli F, Lazzeri E, Parronchi P, Liotta F, Maggi E, Romagnani S, Annunziato F (2008) Human interleukin 17producing cells originate from a CD161+CD4+ T cell precursor. J Exp Med 205:1903-1916

40. Lee AY, Eri R, Lyons AB, Grimm MC, Korner H (2013) CC chemokine ligand 20 and its cognate receptor CCR6 in mucosal T cell immunology and inflammatory bowel disease: odd couple or axis of evil? Front Immunol 4:194

41. Campbell DJ, Butcher EC (2002) Rapid acquisition of tissuespecific homing phenotypes by CD4(+) T cells activated in cutaneous or mucosal lymphoid tissues. J Exp Med 195:135-141

42. Campbell JJ, Haraldsen G, Pan J, Rottman J, Qin S, Ponath P, Andrew DP, Warnke R, Ruffing N, Kassam N, Wu L, Butcher EC (1999) The chemokine receptor CCR4 in vascular recognition by cutaneous but not intestinal memory T cells. Nature 400:776-780

43. Soler D, Humphreys TL, Spinola SM, Campbell JJ (2003) CCR4 versus CCR10 in human cutaneous TH lymphocyte trafficking. Blood 101:1677-1682

44. Groom JR, Luster AD (2011) CXCR3 ligands: redundant, collaborative and antagonistic functions. Immunol Cell Biol 89:207-215

45. Ansel KM, Ngo VN, Hyman PL, Luther SA, Forster R, Sedgwick JD, Browning JL, Lipp M, Cyster JG (2000) A chemokine-driven positive feedback loop organizes lymphoid follicles. Nature 406: 309-314

46. Becattini S, Latorre D, Mele F, Foglierini M, De Gregorio C, Cassotta A, Fernandez B, Kelderman S, Schumacher TN, Corti D, Lanzavecchia A, Sallusto F (2015) T cell immunity. Functional heterogeneity of human memory CD4(+) T cell clones primed by pathogens or vaccines. Science 347:400-406

47. Halle S, Halle O, Forster R (2017) Mechanisms and dynamics of T cell-mediated cytotoxicity in vivo. Trends Immunol 38:432-443

48. Cosmi L, Annunziato F, Galli MIG, Maggi RME, Nagata K, Romagnani S (2000) CRTH2 is the most reliable marker for the detection of circulating human type $2 \mathrm{Th}$ and type $2 \mathrm{~T}$ cytotoxic cells in health and disease. Eur J Immunol 30:2972-2979

49. Hijnen D, Knol EF, Gent YY, Giovannone B, Beijn SJ, Kupper TS, Bruijnzeel-Koomen CA, Clark RA (2013) CD8(+) T cells in the lesional skin of atopic dermatitis and psoriasis patients are an important source of IFN-gamma, IL-13, IL-17, and IL-22. J Invest Dermatol 133:973-979

50. Frentsch M, Stark R, Matzmohr N, Meier S, Durlanik S, Schulz AR, Stervbo U, Jurchott K, Gebhardt F, Heine G, Reuter MA, Betts MR, Busch D, Thiel A (2013) CD40L expression permits CD8+ T cells to execute immunologic helper functions. Blood 122:405-412

51. Cheuk S, Schlums H, Gallais Serezal I, Martini E, Chiang SC, Marquardt N, Gibbs A, Detlofsson E, Introini A, Forkel M, Hoog C, Tjernlund A, Michaelsson J, Folkersen L, Mjosberg J, Blomqvist L, Ehrstrom M, Stahle M, Bryceson YT, Eidsmo L (2017) CD49a expression defines tissue-resident $\mathrm{CD} 8(+) \mathrm{T}$ cells poised for cytotoxic function in human skin. Immunity 46:287-300
52. Linehan JL, Harrison OJ, Han SJ, Byrd AL, Vujkovic-Cvijin I, Villarino AV, Sen SK, Shaik J, Smelkinson M, Tamoutounour S, Collins N, Bouladoux N, Dzutsev A, Rosshart SP, Arbuckle JH, Wang CR, Kristie TM, Rehermann B, Trinchieri G, Brenchley JM, O'Shea JJ, Belkaid Y (2018) Non-classical immunity controls microbiota impact on skin immunity and tissue repair. Cell 172: 784-796 e18

53. Harrison OJ, Linehan JL, Shih HY, Bouladoux N, Han SJ, Smelkinson M, Sen SK, Byrd AL, Enamorado M, Yao C, Tamoutounour S, Van Laethem F, Hurabielle C, Collins N, Paun A, Salcedo R, O'Shea JJ, Belkaid Y (2019) Commensal-specific T cell plasticity promotes rapid tissue adaptation to injury. Science 363. https://doi.org/10.1126/science.aat6280

54. Wolk K, Warszawska K, Hoeflich C, Witte E, Schneider-Burrus S, Witte K, Kunz S, Buss A, Roewert HJ, Krause M, Lukowsky A, Volk HD, Sterry W, Sabat R (2011) Deficiency of IL-22 contributes to a chronic inflammatory disease: pathogenetic mechanisms in acne inversa. J Immunol 186:1228-1239

55. Matusiak L, Szczech J, Bieniek A, Nowicka-Suszko D, Szepietowski JC (2017) Increased interleukin (IL)-17 serum levels in patients with hidradenitis suppurativa: implications for treatment with anti-IL-17 agents. J Am Acad Dermatol 76:670-675

56. Moran B, Sweeney CM, Hughes R, Malara A, Kirthi S, Tobin AM, Kirby B, Fletcher JM (2017) Hidradenitis suppurativa is characterized by dysregulation of the Th17:Treg cell axis, which is corrected by anti-TNF therapy. J Invest Dermatol 137:2389-2395

57. Witte-Handel E, Wolk K, Tsaousi A, Irmer ML, Mossner R, Shomroni O, Lingner T, Witte K, Kunkel D, Salinas G, Jodl S, Schmidt N, Sterry W, Volk HD, Giamarellos-Bourboulis EJ, Pokrywka A, Docke WD, Schneider-Burrus S, Sabat R (2018) The IL-1 pathway is hyperactive in hidradenitis suppurativa and contributes to skin infiltration and destruction. J Invest Dermatol. https://doi.org/10.1016/j.jid.2018.11.018

58. Picardo M, Dell'Anna ML, Ezzedine K, Hamzavi I, Harris JE, Parsad D, Taieb A (2015) Vitiligo. Nat Rev Dis Primers 1:15011

59. Kumar S, Nayak CS, Padhi T, Rao G, Rao A, Sharma VK, Srinivas CR (2014) Epidemiological pattern of psoriasis, vitiligo and atopic dermatitis in India: hospital-based point prevalence. Indian Dermatol Online J 5:S6-S8

60. Boniface K, Seneschal J, Picardo M, Taieb A (2018) Vitiligo: focus on clinical aspects, immunopathogenesis, and therapy. Clin Rev Allergy Immunol 54:52-67

61. Alikhan A, Felsten LM, Daly M, Petronic-Rosic V (2011) Vitiligo: a comprehensive overview part I. Introduction, epidemiology, quality of life, diagnosis, differential diagnosis, associations, histopathology, etiology, and work-up. J Am Acad Dermatol 65:473-491

62. Badri AM, Todd PM, Garioch JJ, Gudgeon JE, Stewart DG, Goudie RB (1993) An immunohistological study of cutaneous lymphocytes in vitiligo. J Pathol 170:149-155

63. Xie H, Zhou F, Liu L, Zhu G, Li Q, Li C, Gao T (2016) Vitiligo: how do oxidative stress-induced autoantigens trigger autoimmunity? J Dermatol Sci 81:3-9

64. He Y, Li S, Zhang W, Dai W, Cui T, Wang G, Gao T, Li C (2017) Dysregulated autophagy increased melanocyte sensitivity to H2O2-induced oxidative stress in vitiligo. Sci Rep 7:42394

65. Mosenson JA, Zloza A, Nieland JD, Garrett-Mayer E, Eby JM, Huelsmann EJ, Kumar P, Denman CJ, Lacek AT, Kohlhapp FJ, Alamiri A, Hughes T, Bines SD, Kaufman HL, Overbeck A, Mehrotra S, Hernandez C, Nishimura MI, Guevara-Patino JA, Le Poole IC (2013) Mutant HSP70 reverses autoimmune depigmentation in vitiligo. Sci Transl Med 5:174ra28

66. Richmond JM, Bangari DS, Essien KI, Currimbhoy SD, Groom JR, Pandya AG, Youd ME, Luster AD, Harris JE (2017) Keratinocyte-derived chemokines orchestrate T-cell positioning 
in the epidermis during vitiligo and may serve as biomarkers of disease. J Invest Dermatol 137:350-358

67. Rashighi M, Agarwal P, Richmond JM, Harris TH, Dresser K, Su MW, Zhou Y, Deng A, Hunter CA, Luster AD, Harris JE (2014) CXCL10 is critical for the progression and maintenance of depigmentation in a mouse model of vitiligo. Sci Transl Med 6:223ra23

68. Wu J, Zhou M, Wan Y, Xu A (2013) CD8+ T cells from vitiligo perilesional margins induce autologous melanocyte apoptosis. Mol Med Rep 7:237-241

69. Witte E, Kokolakis G, Witte K, Warszawska K, Friedrich M, Christou D, Kirsch S, Sterry W, Volk HD, Sabat R, Wolk K (2016) Interleukin-29 induces epithelial production of CXCR3A ligands and T-cell infiltration. J Mol Med (Berl) 94:391-400

70. Dwivedi M, Kemp EH, Laddha NC, Mansuri MS, Weetman AP, Begum R (2015) Regulatory T cells in vitiligo: implications for pathogenesis and therapeutics. Autoimmun Rev 14:49-56

71. Lili Y, Yi W, Ji Y, Yue S, Weimin S, Ming L (2012) Global activation of CD8+ cytotoxic T lymphocytes correlates with an impairment in regulatory $\mathrm{T}$ cells in patients with generalized vitiligo. PLoS One 7:e37513

72. Elela MA, Hegazy RA, Fawzy MM, Rashed LA, Rasheed H (2013) Interleukin 17, interleukin 22 and FoxP3 expression in tissue and serum of non-segmental vitiligo: a case- controlled study on eighty-four patients. Eur J Dermatol 23:350-355

73. Harris JE, Harris TH, Weninger W, Wherry EJ, Hunter CA, Turka LA (2012) A mouse model of vitiligo with focused epidermal depigmentation requires IFN-gamma for autoreactive CD8(+) Tcell accumulation in the skin. J Invest Dermatol 132:1869-1876

74. Frisoli ML, Harris JE (2017) Vitiligo: mechanistic insights lead to novel treatments. J Allergy Clin Immunol 140:654-662

75. Richmond JM, Masterjohn E, Chu R, Tedstone J, Youd ME, Harris JE (2017) CXCR3 depleting antibodies prevent and reverse vitiligo in mice. J Invest Dermatol 137:982-985

76. Oyoshi MK, He R, Kumar L, Yoon J, Geha RS (2009) Cellular and molecular mechanisms in atopic dermatitis. Adv Immunol 102:135-226

77. Tokura Y (2010) Extrinsic and intrinsic types of atopic dermatitis. J Dermatol Sci 58:1-7

78. Bohme M, Wickman M, Lennart Nordvall S, Svartengren M, Wahlgren CF (2003) Family history and risk of atopic dermatitis in children up to 4 years. Clin Exp Allergy 33:1226-1231

79. Uehara M, Kimura C (1993) Descendant family history of atopic dermatitis. Acta Derm Venereol 73:62-63

80. Otsuka A, Nomura T, Rerknimitr P, Seidel JA, Honda T, Kabashima K (2017) The interplay between genetic and environmental factors in the pathogenesis of atopic dermatitis. Immunol Rev 278:246-262

81. Addor FA, Takaoka R, Rivitti EA, Aoki V (2012) Atopic dermatitis: correlation between non-damaged skin barrier function and disease activity. Int J Dermatol 51:672-676

82. Bin L, Leung DY (2016) Genetic and epigenetic studies of atopic dermatitis. Allergy, Asthma Clin Immunol 12:52

83. Saeki H, Kuwata S, Nakagawa H, Etoh T, Yanagisawa M, Miyamoto M, Tokunaga K, Juji T, Shibata Y (1995) Analysis of disease-associated amino acid epitopes on HLA class II molecules in atopic dermatitis. J Allergy Clin Immunol 96:1061-1068

84. Nograles KE, Zaba LC, Shemer A, Fuentes-Duculan J, Cardinale I, Kikuchi T, Ramon M, Bergman R, Krueger JG, Guttman-Yassky E (2009) IL-22-producing “T22” T cells account for upregulated IL-22 in atopic dermatitis despite reduced IL-17-producing TH17 T cells. J Allergy Clin Immunol 123:1244-1252 e2

85. Sabat R, Ouyang W, Wolk K (2014) Therapeutic opportunities of the IL-22-IL-22R1 system. Nat Rev Drug Discov 13:21-38

86. Cornelissen C, Marquardt Y, Czaja K, Wenzel J, Frank J, LuscherFirzlaff J, Luscher B, Baron JM (2012) IL-31 regulates differentiation and filaggrin expression in human organotypic skin models. J Allergy Clin Immunol 129:426-433 33 e1-8

87. Howell MD, Kim BE, Gao P, Grant AV, Boguniewicz M, Debenedetto A, Schneider L, Beck LA, Barnes KC, Leung DY (2007) Cytokine modulation of atopic dermatitis filaggrin skin expression. J Allergy Clin Immunol 120:150-155

88. Wolk K, Haugen HS, Xu W, Witte E, Waggie K, Anderson M, Vom Baur E, Witte K, Warszawska K, Philipp S, Johnson-Leger C, Volk HD, Sterry W, Sabat R (2009) IL-22 and IL-20 are key mediators of the epidermal alterations in psoriasis while IL-17 and IFN-gamma are not. J Mol Med (Berl) 87:523-536

89. Wolk K, Witte E, Wallace E, Docke WD, Kunz S, Asadullah K, Volk HD, Sterry W, Sabat R (2006) IL-22 regulates the expression of genes responsible for antimicrobial defense, cellular differentiation, and mobility in keratinocytes: a potential role in psoriasis. Eur J Immunol 36:1309-1323

90. Guttman-Yassky E, Lowes MA, Fuentes-Duculan J, Zaba LC, Cardinale I, Nograles KE, Khatcherian A, Novitskaya I, Carucci JA, Bergman R, Krueger JG (2008) Low expression of the IL-23/ Th17 pathway in atopic dermatitis compared to psoriasis. J Immunol 181:7420-7427

91. Nomura I, Goleva E, Howell MD, Hamid QA, Ong PY, Hall CF, Darst MA, Gao B, Boguniewicz M, Travers JB, Leung DY (2003) Cytokine milieu of atopic dermatitis, as compared to psoriasis, skin prevents induction of innate immune response genes. J Immunol 171:3262-3269

92. Ong PY, Ohtake T, Brandt C, Strickland I, Boguniewicz M, Ganz T, Gallo RL, Leung DY (2002) Endogenous antimicrobial peptides and skin infections in atopic dermatitis. N Engl J Med 347:1151-1160

93. Wolk K, Mitsui H, Witte K, Gellrich S, Gulati N, Humme D, Witte E, Gonsior M, Beyer M, Kadin ME, Volk HD, Krueger JG, Sterry W, Sabat R (2014) Deficient cutaneous antibacterial competence in cutaneous T-cell lymphomas: role of Th2-mediated biased Th17 function. Clin Cancer Res 20:5507-5516

94. Wolk K, Witte K, Witte E, Raftery M, Kokolakis G, Philipp S, Schonrich G, Warszawska K, Kirsch S, Prosch S, Sterry W, Volk HD, Sabat R (2013) IL-29 is produced by T(H)17 cells and mediates the cutaneous antiviral competence in psoriasis. Sci Transl Med 5:204ra129

95. Christophers E, Henseler T (1987) Contrasting disease patterns in psoriasis and atopic dermatitis. Arch Dermatol Res 279(Suppl): S48-S51

96. Klein PA, Greene WH, Fuhrer J, Clark RA (1997) Prevalence of methicillin-resistant Staphylococcus aureus in outpatients with psoriasis, atopic dermatitis, or HIV infection. Arch Dermatol 133:1463-1465

97. Ong PY (2014) Recurrent MRSA skin infections in atopic dermatitis. J Allergy Clin Immunol Pract 2:396-399

98. Ong PY, Leung DY (2016) Bacterial and viral infections in atopic dermatitis: a comprehensive review. Clin Rev Allergy Immunol 51: 329-337

99. Totte JE, van der Feltz WT, Hennekam M, van Belkum A, van Zuuren EJ, Pasmans SG (2016) Prevalence and odds of Staphylococcus aureus carriage in atopic dermatitis: a systematic review and meta-analysis. Br J Dermatol 175:687-695

100. Jinnestal CL, Belfrage E, Back O, Schmidtchen A, Sonesson A (2014) Skin barrier impairment correlates with cutaneous Staphylococcus aureus colonization and sensitization to skinassociated microbial antigens in adult patients with atopic dermatitis. Int J Dermatol 53:27-33

101. Wollenberg A, Wetzel S, Burgdorf WH, Haas J (2003) Viral infections in atopic dermatitis: pathogenic aspects and clinical management. J Allergy Clin Immunol 112:667-674

102. Paller AS, Tom WL, Lebwohl MG, Blumenthal RL, Boguniewicz M, Call RS, Eichenfield LF, Forsha DW, Rees WC, Simpson EL, Spellman MC, Stein Gold LF, Zaenglein AL, Hughes MH, Zane 
LT, Hebert AA (2016) Efficacy and safety of crisaborole ointment, a novel, nonsteroidal phosphodiesterase 4 (PDE4) inhibitor for the topical treatment of atopic dermatitis (AD) in children and adults. J Am Acad Dermatol 75:494-503 e6

103. Simpson EL, Bieber T, Guttman-Yassky E, Beck LA, Blauvelt A, Cork MJ, Silverberg JI, Deleuran M, Kataoka Y, Lacour JP, Kingo K, Worm M, Poulin Y, Wollenberg A, Soo Y, Graham NM, Pirozzi G, Akinlade B, Staudinger H, Mastey V, Eckert L, Gadkari A, Stahl N, Yancopoulos GD, Ardeleanu M, Solo, Investigators S (2016) Two phase 3 trials of dupilumab versus placebo in atopic dermatitis. N Engl J Med 375:2335-2348

104. Parisi R, Symmons DP, Griffiths CE, Ashcroft DM, Identification, Management of P, Associated ComorbidiTy project t (2013) Global epidemiology of psoriasis: a systematic review of incidence and prevalence. J Invest Dermatol 133:377-385

105. Sterry W (2015) Plaque psoriasis. In: Sterry W, Sabat R, Philipp S (eds) Psoriasis, diagnosis and management. Wiley Blackwell, Chichester, pp 57-75

106. Wolk K, Röwert-Huber HJ, Sabat R (2015) Microscopic skin alterations. In: Sterry W, Sabat R, Philipp S (eds) Psoriasis, diagnosis and management. Wiley Blackwell, Chichester, pp 21-27

107. Heidenreich R, Rocken M, Ghoreschi K (2009) Angiogenesis drives psoriasis pathogenesis. Int J Exp Pathol 90:232-248

108. Eberle FC, Bruck J, Holstein J, Hirahara K, Ghoreschi K (2016) Recent advances in understanding psoriasis. F1000Res 5. https:// doi.org/10.12688/f1000research.7927.1

109. Schon MP, Broekaert SM, Erpenbeck L (2017) Sexy again: the renaissance of neutrophils in psoriasis. Exp Dermatol 26:305-311

110. Henes JC, Ziupa E, Eisfelder M, Adamczyk A, Knaudt B, Jacobs F, Lux J, Schanz S, Fierlbeck G, Spira D, Horger M, Kanz L, Koetter I (2014) High prevalence of psoriatic arthritis in dermatological patients with psoriasis: a cross-sectional study. Rheumatol Int 34:227-234

111. Sterry W, Strober BE, Menter A, International Psoriasis C (2007) Obesity in psoriasis: the metabolic, clinical and therapeutic implications. Report of an interdisciplinary conference and review. Br J Dermatol 157:649-655

112. Takeshita J, Grewal S, Langan SM, Mehta NN, Ogdie A, Van Voorhees AS, Gelfand JM (2017) Psoriasis and comorbid diseases: epidemiology. J Am Acad Dermatol 76:377-390

113. Henseler T, Christophers E (1985) Psoriasis of early and late onset: characterization of two types of psoriasis vulgaris. J Am Acad Dermatol 13:450-456

114. Tiilikainen A, Lassus A, Karvonen J, Vartiainen P, Julin M (1980) Psoriasis and HLA-Cw6. Br J Dermatol 102:179-184

115. Schakel K, Schon MP, Ghoreschi K (2016) Pathogenesis of psoriasis. Hautarzt 67:422-431

116. Witte E, Sabat R (2015) Genetics of psoriasis. In: Sterry W, Sabat R, Philipp S (eds) Psoriasis, diagnosis and management. Wiley Blackwell, Chichester, pp 49-54

117. Cheuk S, Wiken M, Blomqvist L, Nylen S, Talme T, Stahle M, Eidsmo L (2014) Epidermal Th22 and Tc17 cells form a localized disease memory in clinically healed psoriasis. J Immunol 192: $3111-3120$

118. Villanova F, Flutter B, Tosi I, Grys K, Sreeneebus H, Perera GK, Chapman A, Smith CH, Di Meglio P, Nestle FO (2014) Characterization of innate lymphoid cells in human skin and blood demonstrates increase of NKp44+ ILC3 in psoriasis. J Invest Dermatol 134:984-991

119. Ghoreschi K, Laurence A, Yang XP, Tato CM, McGeachy MJ, Konkel JE, Ramos HL, Wei L, Davidson TS, Bouladoux N, Grainger JR, Chen Q, Kanno Y, Watford WT, Sun HW, Eberl G, Shevach EM, Belkaid Y, Cua DJ, Chen W, O'Shea JJ (2010) Generation of pathogenic T(H)17 cells in the absence of TGFbeta signalling. Nature 467:967-971
120. Sabat R, Wolk K (2015) Pathogenesis of psoriasis. In: Sterry W, Sabat R, Philipp S (eds) Psoriasis: diagnosis and management. Wiley-Blackwell, Hoboken, pp 28-48

121. Albanesi C, Cavani A, Girolomoni G (1999) IL-17 is produced by nickel-specific T lymphocytes and regulates ICAM-1 expression and chemokine production in human keratinocytes: synergistic or antagonist effects with IFN-gamma and TNF-alpha. J Immunol 162:494-502

122. Chiricozzi A, Guttman-Yassky E, Suarez-Farinas M, Nograles KE, Tian S, Cardinale I, Chimenti S, Krueger JG (2011) Integrative responses to IL-17 and TNF-alpha in human keratinocytes account for key inflammatory pathogenic circuits in psoriasis. J Invest Dermatol 131:677-687

123. Fossiez F, Djossou O, Chomarat P, Flores-Romo L, Ait-Yahia S, Maat C, Pin JJ, Garrone P, Garcia E, Saeland S, Blanchard D, Gaillard C, Das Mahapatra B, Rouvier E, Golstein P, Banchereau J, Lebecque S (1996) T cell interleukin-17 induces stromal cells to produce proinflammatory and hematopoietic cytokines. J Exp Med 183:2593-2603

124. Homey B, Dieu-Nosjean MC, Wiesenborn A, Massacrier C, Pin JJ, Oldham E, Catron D, Buchanan ME, Muller A, deWaal Malefyt R, Deng G, Orozco R, Ruzicka T, Lehmann P, Lebecque S, Caux C, Zlotnik A (2000) Up-regulation of macrophage inflammatory protein-3 alpha/CCL20 and CC chemokine receptor 6 in psoriasis. J Immunol 164:6621-6632

125. Katz Y, Nadiv O, Beer Y (2001) Interleukin-17 enhances tumor necrosis factor alpha-induced synthesis of interleukins 1,6 , and 8 in skin and synovial fibroblasts: a possible role as a "fine-tuning cytokine" in inflammation processes. Arthritis Rheum 44:2176-2184

126. Liang SC, Tan XY, Luxenberg DP, Karim R, DunussiJoannopoulos K, Collins M, Fouser LA (2006) Interleukin (IL)22 and IL-17 are coexpressed by Th17 cells and cooperatively enhance expression of antimicrobial peptides. J Exp Med 203: 2271-2279

127. Witte E, Kokolakis G, Witte K, Philipp S, Doecke WD, Babel N, Wittig BM, Warszawska K, Kurek A, Erdmann-Keding M, Kunz S, Asadullah K, Kadin ME, Volk HD, Sterry W, Wolk K, Sabat R (2014) IL-19 is a component of the pathogenetic IL-23/IL-17 cascade in psoriasis. J Invest Dermatol 134:2757-2767

128. Holstein J, Fehrenbacher B, Bruck J, Muller-Hermelink E, Schafer I, Carevic M, Schittek B, Schaller M, Ghoreschi K, Eberle FC (2017) Anthralin modulates the expression pattern of cytokeratins and antimicrobial peptides by psoriatic keratinocytes. J Dermatol Sci 87:236-245

129. Huang W, Na L, Fidel PL, Schwarzenberger P (2004) Requirement of interleukin-17A for systemic anti-Candida albicans host defense in mice. J Infect Dis 190:624-631

130. Wolk K, Kunz S, Witte E, Friedrich M, Asadullah K, Sabat R (2004) IL-22 increases the innate immunity of tissues. Immunity 21:241-254

131. Wolk K, Witte E, Warszawska K, Schulze-Tanzil G, Witte K, Philipp S, Kunz S, Docke WD, Asadullah K, Volk HD, Sterry W, Sabat R (2009) The Th17 cytokine IL-22 induces IL-20 production in keratinocytes: a novel immunological cascade with potential relevance in psoriasis. Eur J Immunol 39:3570-3581

132. Weiss B, Wolk K, Grunberg BH, Volk HD, Sterry W, Asadullah K, Sabat R (2004) Cloning of murine IL-22 receptor alpha 2 and comparison with its human counterpart. Genes Immun 5:330-336

133. Martin JC, Wolk K, Beriou G, Abidi A, Witte-Handel E, Louvet C, Kokolakis G, Drujont L, Dumoutier L, Renauld JC, Sabat R, Josien R (2017) Limited presence of IL-22 binding protein, a natural IL-22 inhibitor, strengthens psoriatic skin inflammation. J Immunol 198:3671-3678

134. Schroder K, Hertzog PJ, Ravasi T, Hume DA (2004) Interferongamma: an overview of signals, mechanisms and functions. $\mathrm{J}$ Leukoc Biol 75:163-189 
135. Van Raemdonck K, Van den Steen PE, Liekens S, Van Damme J, Struyf S (2015) CXCR3 ligands in disease and therapy. Cytokine Growth Factor Rev 26:311-327

136. Beutler B, Cerami A (1989) The biology of cachectin/TNF-a primary mediator of the host response. Annu Rev Immunol 7:625-655

137. Witte K, Witte E, Sabat R, Wolk K (2010) IL-28A, IL-28B, and IL-29: promising cytokines with type I interferon-like properties. Cytokine Growth Factor Rev 21:237-251

138. Hawkes JE, Chan TC, Krueger JG (2017) Psoriasis pathogenesis and the development of novel targeted immune therapies. J Allergy Clin Immunol 140:645-653

139. Welsch K, Holstein J, Laurence A, Ghoreschi K (2017) Targeting JAK/STAT signalling in inflammatory skin diseases with small molecule inhibitors. Eur J Immunol 47:1096-1107

140. Ferlay J, Soerjomataram I, Dikshit R, Eser S, Mathers C, Rebelo M, Parkin DM, Forman D, Bray F (2015) Cancer incidence and mortality worldwide: sources, methods and major patterns in GLOBOCAN 2012. Int J Cancer 136:E359-E386

141. Garbe C, Peris K, Hauschild A, Saiag P, Middleton M, Bastholt L, Grob JJ, Malvehy J, Newton-Bishop J, Stratigos AJ, Pehamberger H, Eggermont AM, European Dermatology F, European Association of D-O, European Organisation for R, Treatment of C (2016) Diagnosis and treatment of melanoma. European consensus-based interdisciplinary guideline - update 2016. Eur J Cancer 63:201-217

142. Zbytek B, Carlson JA, Granese J, Ross J, Mihm MC Jr, Slominski A (2008) Current concepts of metastasis in melanoma. Expert Rev Dermatol 3:569-585

143. Gilchrest BA, Eller MS, Geller AC, Yaar M (1999) The pathogenesis of melanoma induced by ultraviolet radiation. $\mathrm{N}$ Engl J Med 340:1341-1348

144. Bastian BC (2014) The molecular pathology of melanoma: an integrated taxonomy of melanocytic neoplasia. Annu Rev Pathol 9:239-271

145. Candido S, Rapisarda V, Marconi A, Malaponte G, Bevelacqua V, Gangemi P, Scalisi A, McCubrey JA, Maestro R, Spandidos DA, Fenga C, Libra M (2014) Analysis of the B-RafV600E mutation in cutaneous melanoma patients with occupational sun exposure. Oncol Rep 31:1079-1082

146. Cohen C, Zavala-Pompa A, Sequeira JH, Shoji M, Sexton DG, Cotsonis G, Cerimele F, Govindarajan B, Macaron N, Arbiser JL (2002) Mitogen-actived protein kinase activation is an early event in melanoma progression. Clin Cancer Res 8:3728-3733

147. Boon T, Coulie PG, Van den Eynde BJ, van der Bruggen P (2006) Human $\mathrm{T}$ cell responses against melanoma. Annu Rev Immunol 24:175-208

148. Speeckaert R, van Geel N, Vermaelen KV, Lambert J, Van Gele M, Speeckaert MM, Brochez L (2011) Immune reactions in benign and malignant melanocytic lesions: lessons for immunotherapy. Pigment Cell Melanoma Res 24:334-344

149. Azijli K, Stelloo E, Peters GJ, AJ VDE (2014) New developments in the treatment of metastatic melanoma: immune checkpoint inhibitors and targeted therapies. Anticancer Res 34:1493-1505

150. Garbe C, Eigentler TK, Keilholz U, Hauschild A, Kirkwood JM (2011) Systematic review of medical treatment in melanoma: current status and future prospects. Oncologist 16:5-24

151. Silva IP, Long GV (2017) Systemic therapy in advanced melanoma: integrating targeted therapy and immunotherapy into clinical practice. Curr Opin Oncol 29:484-492

152. Lawrence MS, Stojanov P, Polak P, Kryukov GV, Cibulskis K, Sivachenko A, Carter SL, Stewart C, Mermel CH, Roberts SA, Kiezun A, Hammerman PS, McKenna A, Drier Y, Zou L, Ramos AH, Pugh TJ, Stransky N, Helman E, Kim J, Sougnez C, Ambrogio L, Nickerson E, Shefler E, Cortes ML, Auclair D, Saksena G, Voet D, Noble M, DiCara D, Lin P, Lichtenstein L, Heiman DI, Fennell T, Imielinski M, Hernandez B, Hodis E, Baca
S, Dulak AM, Lohr J, Landau DA, Wu CJ, Melendez-Zajgla J, Hidalgo-Miranda A, Koren A, McCarroll SA, Mora J, Crompton B, Onofrio R, Parkin M, Winckler W, Ardlie K, Gabriel SB, Roberts CWM, Biegel JA, Stegmaier K, Bass AJ, Garraway LA, Meyerson M, Golub TR, Gordenin DA, Sunyaev S, Lander ES, Getz G (2013) Mutational heterogeneity in cancer and the search for new cancer-associated genes. Nature 499:214-218

153. Schumacher TN, Schreiber RD (2015) Neoantigens in cancer immunotherapy. Science 348:69-74

154. Azimi F, Scolyer RA, Rumcheva P, Moncrieff M, Murali R, McCarthy SW, Saw RP, Thompson JF (2012) Tumor-infiltrating lymphocyte grade is an independent predictor of sentinel lymph node status and survival in patients with cutaneous melanoma. J Clin Oncol 30:2678-2683

155. Tuthill RJ, Unger JM, Liu PY, Flaherty LE, Sondak VK, Southwest Oncology G (2002) Risk assessment in localized primary cutaneous melanoma: a Southwest Oncology Group study evaluating nine factors and a test of the Clark logistic regression prediction model. Am J Clin Pathol 118:504-511

156. Jandus C, Speiser D, Romero P (2009) Recent advances and hurdles in melanoma immunotherapy. Pigment Cell Melanoma Res 22:711-723

157. Fourcade J, Zarour HM (2013) Strategies to reverse melanomainduced T-cell dysfunction. Clin Dermatol 31:251-256

158. Antony PA, Restifo NP (2005) CD4+CD25+ T regulatory cells, immunotherapy of cancer, and interleukin-2. J Immunother 28: $120-128$

159. Jacobs JF, Nierkens S, Figdor CG, de Vries IJ, Adema GJ (2012) Regulatory T cells in melanoma: the final hurdle towards effective immunotherapy? Lancet Oncol 13:e32-e42

160. Ouyang Z, Wu H, Li L, Luo Y, Li X, Huang G (2016) Regulatory T cells in the immunotherapy of melanoma. Tumour Biol 37:77-85

161. Baumgartner J, Wilson C, Palmer B, Richter D, Banerjee A, McCarter M (2007) Melanoma induces immunosuppression by up-regulating FOXP3(+) regulatory T cells. J Surg Res 141:72-77

162. Sakaguchi S, Miyara M, Costantino CM, Hafler DA (2010) FOXP3+ regulatory $\mathrm{T}$ cells in the human immune system. Nat Rev Immunol 10:490-500

163. Bluestone JA, Abbas AK (2003) Natural versus adaptive regulatory T cells. Nat Rev Immunol 3:253-257

164. von Herrath MG, Harrison LC (2003) Antigen-induced regulatory T cells in autoimmunity. Nat Rev Immunol 3:223-232

165. Nizar S, Meyer B, Galustian C, Kumar D, Dalgleish A (2010) T regulatory cells, the evolution of targeted immunotherapy. Biochim Biophys Acta 1806:7-17

166. Wang HY, Lee DA, Peng G, Guo Z, Li Y, Kiniwa Y, Shevach EM, Wang RF (2004) Tumor-specific human CD4+ regulatory T cells and their ligands: implications for immunotherapy. Immunity 20 : $107-118$

167. Ahmadzadeh M, Pasetto A, Jia L, Deniger DC, Stevanovic S, Robbins PF, Rosenberg SA (2019) Tumor-infiltrating human CD4(+) regulatory T cells display a distinct TCR repertoire and exhibit tumor and neoantigen reactivity. Sci Immunol 4. https:// doi.org/10.1126/sciimmunol.aao4310

168. Vence L, Palucka AK, Fay JW, Ito T, Liu YJ, Banchereau J, Ueno $\mathrm{H}$ (2007) Circulating tumor antigen-specific regulatory T cells in patients with metastatic melanoma. Proc Natl Acad Sci U S A 104: 20884-20889

169. Fourcade J, Sun Z, Kudela P, Janjic B, Kirkwood JM, El-Hafnawy T, Zarour HM (2010) Human tumor antigen-specific helper and regulatory $\mathrm{T}$ cells share common epitope specificity but exhibit distinct T cell repertoire. J Immunol 184:6709-6718

170. Francois V, Ottaviani S, Renkvist N, Stockis J, Schuler G, Thielemans K, Colau D, Marchand M, Boon T, Lucas S, van der Bruggen P (2009) The CD4(+) T-cell response of melanoma 
patients to a MAGE-A3 peptide vaccine involves potential regulatory T cells. Cancer Res 69:4335-4345

171. Curiel TJ, Coukos G, Zou L, Alvarez X, Cheng P, Mottram P, Evdemon-Hogan M, Conejo-Garcia JR, Zhang L, Burow M, Zhu Y, Wei S, Kryczek I, Daniel B, Gordon A, Myers L, Lackner A, Disis ML, Knutson KL, Chen L, Zou W (2004) Specific recruitment of regulatory $\mathrm{T}$ cells in ovarian carcinoma fosters immune privilege and predicts reduced survival. Nat Med 10:942-949

172. Knol AC, Nguyen JM, Quereux G, Brocard A, Khammari A, Dreno B (2011) Prognostic value of tumor-infiltrating Foxp3+ Tcell subpopulations in metastatic melanoma. Exp Dermatol 20: 430-434

173. Quezada SA, Peggs KS, Curran MA, Allison JP (2006) CTLA4 blockade and GM-CSF combination immunotherapy alters the intratumor balance of effector and regulatory $\mathrm{T}$ cells. J Clin Invest 116:1935-1945

174. Wei S, Kryczek I, Zou W (2006) Regulatory T-cell compartmentalization and trafficking. Blood 108:426-431

175. Kimpfler S, Sevko A, Ring S, Falk C, Osen W, Frank K, Kato M, Mahnke K, Schadendorf D, Umansky V (2009) Skin melanoma development in ret transgenic mice despite the depletion of CD25+Foxp3+ regulatory $\mathrm{T}$ cells in lymphoid organs. J Immunol 183:6330-6337

176. Munn DH, Mellor AL (2007) Indoleamine 2,3-dioxygenase and tumor-induced tolerance. J Clin Invest 117:1147-1154

177. Brody JR, Costantino CL, Berger AC, Sato T, Lisanti MP, Yeo CJ, Emmons RV, Witkiewicz AK (2009) Expression of indoleamine 2, 3 -dioxygenase in metastatic malignant melanoma recruits regulatory $\mathrm{T}$ cells to avoid immune detection and affects survival. Cell Cycle 8:1930-1934

178. Shabaneh TB, Molodtsov AK, Steinberg SM, Zhang P, Torres GM, Mohamed GA, Boni A, Curiel TJ, Angeles CV, Turk MJ (2018) Oncogenic BRAF(V600E) governs regulatory T-cell recruitment during melanoma tumorigenesis. Cancer Res 78: 5038-5049

179. Ross MI, Gershenwald JE (2011) Evidence-based treatment of early-stage melanoma. J Surg Oncol 104:341-353

180. Atkins MB, Lotze MT, Dutcher JP, Fisher RI, Weiss G, Margolin K, Abrams J, Sznol M, Parkinson D, Hawkins M, Paradise C, Kunkel L, Rosenberg SA (1999) High-dose recombinant interleukin 2 therapy for patients with metastatic melanoma: analysis of 270 patients treated between 1985 and 1993. J Clin Oncol 17: 2105-2116

181. Cesana GC, DeRaffele G, Cohen S, Moroziewicz D, Mitcham J, Stoutenburg J, Cheung K, Hesdorffer C, Kim-Schulze S, Kaufman HL (2006) Characterization of CD4+CD25+ regulatory T cells in patients treated with high-dose interleukin-2 for metastatic melanoma or renal cell carcinoma. J Clin Oncol 24:1169-1177

182. Thornton AM, Donovan EE, Piccirillo CA, Shevach EM (2004) Cutting edge: IL-2 is critically required for the in vitro activation of CD4+CD25+ T cell suppressor function. J Immunol 172:65196523

183. Ascierto PA, McArthur GA, Dreno B, Atkinson V, Liszkay G, Di Giacomo AM, Mandala M, Demidov L, Stroyakovskiy D, Thomas L, de la Cruz-Merino L, Dutriaux C, Garbe C, Yan Y, Wongchenko M, Chang I, Hsu JJ, Koralek DO, Rooney I, Ribas A, Larkin J (2016) Cobimetinib combined with vemurafenib in advanced BRAF(V600)-mutant melanoma (coBRIM): updated efficacy results from a randomised, double-blind, phase 3 trial. Lancet Oncol 17:1248-1260

184. Robert C, Karaszewska B, Schachter J, Rutkowski P, Mackiewicz A, Stroiakovski D, Lichinitser M, Dummer R, Grange F, Mortier L, Chiarion-Sileni V, Drucis K, Krajsova I, Hauschild A, Lorigan P, Wolter P, Long GV, Flaherty K, Nathan P, Ribas A, Martin AM, Sun P, Crist W, Legos J, Rubin SD, Little SM, Schadendorf D
(2015) Improved overall survival in melanoma with combined dabrafenib and trametinib. N Engl J Med 372:30-39

185. Wilmott JS, Long GV, Howle JR, Haydu LE, Sharma RN, Thompson JF, Kefford RF, Hersey P, Scolyer RA (2012) Selective BRAF inhibitors induce marked T-cell infiltration into human metastatic melanoma. Clin Cancer Res 18:1386-1394

186. Selby MJ, Engelhardt JJ, Quigley M, Henning KA, Chen T, Srinivasan M, Korman AJ (2013) Anti-CTLA-4 antibodies of IgG2a isotype enhance antitumor activity through reduction of intratumoral regulatory T cells. Cancer Immunol Res 1:32-42

187. Hodi FS, O'Day SJ, McDermott DF, Weber RW, Sosman JA, Haanen JB, Gonzalez R, Robert C, Schadendorf D, Hassel JC, Akerley W, van den Eertwegh AJ, Lutzky J, Lorigan P, Vaubel JM, Linette GP, Hogg D, Ottensmeier CH, Lebbe C, Peschel C, Quirt I, Clark JI, Wolchok JD, Weber JS, Tian J, Yellin MJ, Nichol GM, Hoos A, Urba WJ (2010) Improved survival with ipilimumab in patients with metastatic melanoma. N Engl J Med 363:711-723

188. Schadendorf D, Hodi FS, Robert C, Weber JS, Margolin K, Hamid O, Patt D, Chen TT, Berman DM, Wolchok JD (2015) Pooled analysis of long-term survival data from phase II and phase III trials of ipilimumab in unresectable or metastatic melanoma. $\mathrm{J}$ Clin Oncol 33:1889-1894

189. Romano E, Kusio-Kobialka M, Foukas PG, Baumgaertner P, Meyer C, Ballabeni P, Michielin O, Weide B, Romero P, Speiser DE (2015) Ipilimumab-dependent cell-mediated cytotoxicity of regulatory T cells ex vivo by nonclassical monocytes in melanoma patients. Proc Natl Acad Sci U S A 112:6140-6145

190. Sharma A, Subudhi SK, Blando J, Scutti J, Vence L, Wargo J, Allison JP, Ribas A, Sharma P (2019) Anti-CTLA-4 immunotherapy does not deplete FOXP3(+) regulatory T cells (Tregs) in human cancers. Clin Cancer Res 25:1233-1238

191. Simeone E, Gentilcore G, Giannarelli D, Grimaldi AM, Caraco C, Curvietto M, Esposito A, Paone M, Palla M, Cavalcanti E, Sandomenico F, Petrillo A, Botti G, Fulciniti F, Palmieri G, Queirolo P, Marchetti P, Ferraresi V, Rinaldi G, Pistillo MP, Ciliberto G, Mozzillo N, Ascierto PA (2014) Immunological and biological changes during ipilimumab treatment and their potential correlation with clinical response and survival in patients with advanced melanoma. Cancer Immunol Immunother 63:675-683

192. Tang F, Du X, Liu M, Zheng P, Liu Y (2018) Anti-CTLA-4 antibodies in cancer immunotherapy: selective depletion of intratumoral regulatory $\mathrm{T}$ cells or checkpoint blockade? Cell Biosci 8:30

193. Specenier P (2016) Nivolumab in melanoma. Expert Rev Anticancer Ther 16:1247-1261

194. Woods DM, Ramakrishnan R, Laino AS, Berglund A, Walton K, Betts BC, Weber JS (2018) Decreased suppression and increased phosphorylated STAT3 in regulatory T cells are associated with benefit from adjuvant PD-1 blockade in resected metastatic melanoma. Clin Cancer Res 24:6236-6247

195. Kugel CH 3rd, Douglass SM, Webster MR, Kaur A, Liu Q, Yin X, Weiss SA, Darvishian F, Al-Rohil RN, Ndoye A, Behera R, Alicea GM, Ecker BL, Fane M, Allegrezza MJ, Svoronos N, Kumar V, Wang DY, Somasundaram R, Hu-Lieskovan S, Ozgun A, Herlyn M, Conejo-Garcia JR, Gabrilovich D, Stone EL, Nowicki TS, Sosman J, Rai R, Carlino MS, Long GV, Marais R, Ribas A, Eroglu Z, Davies MA, Schilling B, Schadendorf D, Xu W, Amaravadi RK, Menzies AM, McQuade JL, Johnson DB, Osman I, Weeraratna AT (2018) Age correlates with response to anti-PD1, reflecting age-related differences in Intratumoral effector and regulatory T-cell populations. Clin Cancer Res 24:5347-5356

Publisher's note Springer Nature remains neutral with regard to jurisdictional claims in published maps and institutional affiliations. 